\title{
On reconstructing Giraffa sivalensis, an extinct giraffid from the Siwalik hills, India
}

Sybrand J van Sittert, Graham Mitchell

Giraffa sivalensis occurred during the Plio-Pleistocene period and probably represents the terminal species of the genus in Southern Asia. The holotype is an almost perfectly preserved cervical vertebra of disputed anatomical location. Although there is also uncertainty regarding this animal's size, other specimens that have been assigned to this species include fragments of two humeri, a radius, metacarpi and teeth. Here we estimate neck length, leg length and body mass using interspecific and, unusually, ontogenetic allometry of extant giraffe skeletal parameters. The appropriateness of each equation to estimate body mass was evaluated by calculating the prediction error incurred in both extant giraffes (G. camelopardalis) and okapis (Okapia johnstoni). It followed that the equations with the lowest prediction error in both species were considered robust enough to use in G. sivalensis. The size of $G$. sivalensis, based on the holotype, is proposed as 400 $\mathrm{kg}$ (range $228 \mathrm{~kg}-575 \mathrm{~kg}$ ), with a neck length of approximately $147 \mathrm{~cm}$ and a height of $390 \mathrm{~cm}$. The molar lengths of tooth specimens considered agree with this size estimate. The humerus was the most appropriate long bone to establish body mass, which estimates a heavier animal of ca $790 \mathrm{~kg}$. The discrepancy with the vertebral body weight estimate might indicate sexual dimorphism. Radial and metacarpal specimens estimate $G$. sivalensis to be as heavy as extant giraffes. This may indicate that the radius and metacarpus are unsuitable for body mass predictions in Giraffa spp. Alternatively, certain long bones may have belonged to another long legged giraffid that occurred during the same period and locality as G. sivalensis. We have concluded that if sexual dimorphism was present then males would have been about twice the size of females. If sexual dimorphism was not present and all bones were correctly attributed to this species, then G. sivalensis had a slender neck with a relatively stocky body. 
3 Giraffa sivalensis (Falconer \& Cautley, 1843) was the first extinct Giraffa species to be

4 discovered, yet neither a complete skull nor specimens related to the holotype vertebra have been

5 found. Notwithstanding this limitation, many fossil specimens have been assigned as belonging

6 to this species, without adequate consideration of its size or without explicitly citing the

7 stratigraphic horizon of discovery (Table S1). In addition, many of the discovered specimens

8 have only been described in the Fauna Antiqua Sivalensis, which is a collection of Falconer's

9 publications and unpublished notes (Murchison, 1868). Although all the plates (notably plate E) within the Fauna Antiqua Sivalensis are well described (Falconer \& Murchison, 1867), many of them have never been published.

History of G. sivalensis discovery

In 1838 Cautley briefly described the discovery of a remarkable vertebra in the Siwalik Hills in India. He believed the specimen to be very similar to that of extant giraffes - a significant statement, because up until that time no other fossil Giraffa species were known. Falconer and Cautley (1843) subsequently named the species Camelopardalis sivalensis and assigned the fossil, which was to become the holotype (Badam, 1979), as a third cervical vertebra. However, Lydekker (1885a) disputed this and proposed that the holotype was in actual fact a fifth cervical vertebra of a 'very small individual'. Since Cautley's discovery, other Giraffa-like fossils have also been found in Asia, Europe and Africa, subsequently leading to proposals for species such as G. priscilla, G. jumae, G. stillei, G. gracilis, G. pygmaea and G. punjabiensis. The references 
to these fossil specimens are extensive, incomplete and confusing as can be seen by the references to G. sivalensis alone in Table S1.

Geographic and stratigraphic distribution of fossils

Matthew (1929) placed the upper Siwalik deposits, where G. sivalensis fossils and nearly all Siwalik fauna discovered by early writers such a Falconer have been found (Lydekker, 1876), as part of the Pinjor zone (Gaur, Vasishat \& Chopra, 1985; Akhtar et al., 1991; Nanda, 2002, 2008; Bhatti, 2004). The Pinjor zone dates to roughly 2.58 to 0.6 million years ago, placing the fauna discovered in this site as originating during the late Pliocene / early Pleistocene (Nanda, 2008). The site of discovery of the holotype for G. sivalensis was presented by Falconer and Cautley (1843) only as 'the Sewalik range to the west of the river Jumna' (currently the Yamuna river). Although Spamer, Daeschler \& Vostreys-Shapiro (1995) described the locality as 'Siwalik Hills, near Hardwar, Uttar Pradesh', this is unlikely as Hardwar is east of the Yamuna. We therefore believe the locality was probably in the vicinity of the current Shivalik fossil park, Saketi, Himachal Pradesh, India (Figure 1).

\section{Size estimates and controversy}

Size estimates of G. sivalensis have been inadequate or contradictory. For example, it has been proposed that G. sivalensis was about 'one third shorter' with a neck about 'one tenth more slender' than extant giraffes (Falconer \& Cautley, 1843), and that the holotype belonged to a very small individual (Lydekker, 1885a), that it had the same sized cranium as extant giraffes but with a shorter neck (Lydekker, 1876), that it was a large species but smaller than extant giraffes (Bhatti, 2004, p 155), that it was of comparable size to modern giraffes (Bhatti, 2004, p.255), that it was larger than extant giraffes (Mitchell \& Skinner, 2003) and that certain proportions of 
46 the species' neck were larger than extant giraffes (Lydekker, 1876, p.105). Additional fossil

47 specimens originally thought to belong to a separate species, G. affinis (Falconer \& Cautley,

48 1843), were subsequently shown to belong to G. sivalensis and are currently believed to indicate

49 a larger individual of the species (Lydekker, 1876, p.105; Bhatti, 2004, p140). Table 1

50 summarises previous size estimates for G. sivalensis.

51

In this paper we outline and clarify the relevant information about G. sivalensis and its remains.

53 In addition, we have made new estimates of its size and shape. 


\section{Materials and Methods}

\section{Studied material and dimensions measured}

All postcranial specimens assigned to $G$. sivalensis that were available at the Natural History Museum in London were studied. From these specimens, body and neck size estimates were calculated using giraffe ontogenetic or available interspecific allometric equations. The only vertebra measured was the holotype (OR39747, Figure 2), a cervical which had been extensively described by Falconer and Cautley (1843). A caudal fragment of a 'fourth' cervical (OR39748; Lydekker, 1885a), also described as a second cervical by Falconer (1845), as well as a caudal part of a 'third' cervical (OR39746; Lydekker, 1885a) were missing from the Siwalik collection at the Natural History Museum. Dimensions were measured with a vernier calliper and included: vertebral body length, cranial vertebral body height, cranial vertebral body width, caudal vertebral body height, caudal vertebral body width and spinous process length (Figure 2).

Additional postcranial specimens assigned to G. sivalensis held at the Natural History Museum include fragments of two humeri (OR39749 and OR17136; Figure 3 and Figure 4 respectively), a fragment of a radius/ulna (OR17130) and various fragments of metacarpi and phalanges. All metacarpal specimens except OR39750 were avoided due to the unclear numbering of specimens and deformation of the fossils. Measurements of the long bones included length, midshaft circumference and midshaft diameter in craniocaudal and transverse planes. The length and circumference measurements were done with a measuring tape, while the cross sectional diameters were done with a vernier calliper. 
Because there is no complete G. sivalensis skeleton its shape needs to be inferred as analogous to the only other extant Giraffa: G. camelopardalis. One of the methods of inferring body size from a model animal or animals requires that regression equations in the form $y=m x^{b}$ (Huxley, 1932) be constructed. These regression equations can be based on data from different species (interspecific allometry), within the growth phase of a single animal (ontogenetic allometry) or amongst adult animals of different size but within the same species (static allometry). We applied ontogenetic as well as interspecific allometric equations to predict body mass in this case.

Ontogenetic data were obtained from previous studies by the authors (Mitchell, van Sittert \& Skinner, 2009; van Sittert, Skinner \& Mitchell, 2010, 2015). These data were used to construct allometric equations to describe body mass or body dimensions. The dimensions used from ontogenetic vertebral data are summarised in Table 2. Interspecific regression equations were sourced from previously published work (Anderson, Hall-Martin \& Russell, 1985; Roth, 1990; Scott, 1990; Campione \& Evans, 2012). The dimensions measured for the long bone ontogenetic data are summarised in Table 3

There are inherent problems associated with using dental measurements as body size predictors, especially when only a single tooth is used (Damuth, 1990; Fortelius, 1990; Janis, 1990). Nevertheless, we have estimated size from teeth originally measured by Falconer \& Cautley (1843), even though these teeth were initially assigned to a new species G. affinis, a species that was eventually abandoned (Lydekker, 1883). Uncertainty regarding these teeth specimens persisted until recent times (Spamer, Daeschler \& Vostreys-Shapiro, 1995). Teeth specimens 
described by authors other than Falconer and Cautley which are noted in Supplementary Table 1 were not evaluated further as there was either uncertainty regarding the authors' species association (Lydekker, 1876), or the teeth specimens were not necessarily collected in the vicinity or stratigraphical layer of fossils described by Falconer and Cautley (Lydekker, 1878), or because certain specimens were deciduous. Table 4 presents dental specimens as well as dimensions as measured by Falconer and Cautley (1843). Body masses were estimated from regression equations established by Damuth (1990).

\section{Statistical analyses}

Allometric equations were generated from bivariate data through ordinary least squares regression. To facilitate this, measurements were logarithmically transformed to base $\boldsymbol{e}$ prior to analyses. According to Warton et al. (2006), ordinary least squares regression is appropriate when one wishes to predict $\mathrm{y}$ from $\mathrm{x}$, even when $\mathrm{x}$ contains measurement error, as long as the results are interpreted in the context of 'predicting y from x measured with error'. It is worth noting that there is controversy regarding the practice of logarithmically transforming data in scaling studies (Packard, Boardman \& Birchard, 2009, 2010; Cawley \& Janacek, 2010; Packard, 2013). The main argument is whether error becomes larger as body mass increases (multiplicative error), in which case logarithmic transformation is appropriate, or whether there is no correlation between error and body mass, in which case logarithmic transformation is not appropriate (Glazier, 2013). The debate is ongoing and will not be reviewed here. In this study we selected the method of log-transformation of data as it enables more convenient comparison among similar datasets. 
122 Because body dimensions (especially body masses) can be predicted by different equations and

123 by different fossil specimens, the predictions need to be validated. If regression equations had

124 reasonable power in estimating body mass in both extant giraffids ( $G$. camelopardalis and

125 O.johnstoni), then they were regarded as robust enough to extrapolate to G. sivalensis as well.

126 Therefore, dimensions of 10 okapi skeletons were recorded in addition to data obtained from

127 G. camelopardalis. The okapi skeletons were housed in various museums and were recorded as

128 the opportunities presented themselves (Table 5). Adult okapi specimens were assumed to have

129 weighed $250 \mathrm{~kg}$, with a range of $200 \mathrm{~kg}$ to $300 \mathrm{~kg}$ (Lindsey \& Bennett, 1999; Stuart \& Stuart,

130 2006). The mature okapi specimens were identified through additional data associated with each

131 museum specimen as well as by the degree of fusion of the epiphyses. The robustness of giraffe

132 ontogenetic as well as interspecific equations to predict body mass in both adult giraffes and

133 adult okapis correctly were assessed through the percent prediction error, calculated according to

134 Smith (1984) and van Valkenburgh (1990):

135

136 ((Observed value-Predicted value)/ Predicted value) x 100

Assumptions made

139 One of the major assumptions of this study is that G. sivalensis dimensions can be modelled

140 from G. camelopardalis ontogeny. Although it is unusual to model an animal from the ontogeny

141 of a different species it is not unique (an example is Roth, 1990). In assigning the holotype to a

142 specific vertebra, we also assumed that there would be broad similarity in shape between the

143 cervical vertebrae of G. sivalensis and G. camelopardalis. Falconer and Cautley (1843)

144 illustrated this assumption to be the case for many but not all features of the holotype vertebra. 
145 Another assumption was that the specimens used came from the same Giraffa species. We tried 146 to use only those specimens that were clearly attributable to the Plio-Pleistocene and to the 147 vicinity of the holotype discovery (Figure 1), to limit possible confusion with other Giraffa 148 species like G. punjabiensis. However, in some instances these criteria were not clear due to the 149 lack of other samples or information, as in the discussion of vertebrae OR39746 and OR39748.

150 Lastly, in terms of estimating body proportions in adult animals based on vertebral length, 151 similarity in shape to G. camelopardalis was assumed. 
152

153

154

155

156

157

158

\section{Results}

Dimensions measured

The OR39747 and long bone dimensions measured are summarised in Table 2 and Table 3 respectively, and where applicable the dimensions contain the equivalent measured values according to Falconer and Cautley (1843). Except for the cranial vertebral body height, our measurements on OR39747 are within 1\% to 5\% of that reported by Falconer and Cautley (1843). Dimensions measured from okapi skeletons are presented in Table 5. Table 5 also contains predictions and prediction errors for okapi vertebral neck length based on $G$. camelopardalis ontogenetic data.

\section{Predictions based on vertebra OR39747}

Based on G. camelopardalis ontogenetic data, the average of dorsal and ventral neck length including soft tissue in $G$. sivalensis was $1467 \mathrm{~mm}\left(y=1.55 x^{0.859}\right)$, the vertebral neck length excluding soft tissue was $1270 \mathrm{~mm}\left(y=10.66 x^{0.902}\right)$ and the foreleg (hoof to withers) height in the living G. sivalensis adult was $2540 \mathrm{~mm}\left(y=7.61 x^{0.663}\right.$, Table 6$)$. This would mean that the reaching height of $G$. sivalensis was around $3.9 \mathrm{~m}$.

The different vertebral dimensions predict the body mass to be within a range of $228 \mathrm{~kg}$ to 575 $\mathrm{kg}$, with an average of $373 \mathrm{~kg}$ (Table 7, 95\% Confidence interval (CI) $\pm 168 \mathrm{~kg}$ ). We identified which of these dimensions could predict body mass accurately across species by calculating prediction errors when applying the G. camelopardalis regression equations to both extant giraffes and okapis. Naturally, because the predictions were done using G. camelopardalis ontogenetic allometry, the G. camelopardalis prediction errors were lowest ( $8 \%$ to $50 \%$ ). 
175 Predictions for okapi body mass, however, ranged from $17 \%$ to $99 \%$. The only variable which

176 provided relatively low body mass prediction errors in both okapi (17\%) and G. camelopardalis

177 (25\%) was the caudal vertebral body dorsoventral height. This dimension predicts a body mass

178 of $390 \mathrm{~kg}$ in G. sivalensis if we consider OR39747 as a third cervical. If OR39747 was

179

180

181

182

183

184

185

186

187

188

189

190

191

192

193

194

195

196

197 considered a fourth or fifth cervical, body mass predictions will be $274 \mathrm{~kg}\left(y=0.0011 x^{\wedge 3.128}\right)$ or $187 \mathrm{~kg}\left(y=0.0004 x^{\wedge 3.285}\right)$ respectively (Table 7).

\section{Predictions based on long bone dimensions}

All of the G. sivalensis long bone specimens available at the Natural History Museum were incomplete proximally and/or distally. It was clear, nevertheless, that the bones had a similar slender appearance of extant giraffes and were elongated. Humeral specimen OR39749 was almost complete except for the proximal metaphysis, which has clearly broken off at the physeal line of a subadult animal. Regarding the radius/ulna specimen, the bones' fusion at the midshaft was not complete as in modern giraffes, where the two bones are indistinguishable at midshaft in adults. The metacarpus specimen included in the study had the same caudal 'columns' or caudal groove as those evident in the extant giraffe (Solounias, 1999; van Schalkwyk, 2004; van Schalkwyk, Skinner \& Mitchell, 2004) as well as in those of the okapi (own observation).

As no bones were complete length wise, bone length could not be used as a predictor for body mass which, in any case, has been shown to be a poor estimator of body mass in other taxa (Scott, 1990). Based on circumferences of the humeri (OR39749 and OR17136) and using G. camelopardalis ontogenetic data these specimens may have belonged to animals with body weight in the range of $770 \mathrm{~kg}$ to $810 \mathrm{~kg}$. An extant giraffe of this body mass would have a 
198 humerus length of about $477 \mathrm{~mm}$ to $484 \mathrm{~mm}\left(y=63.2(\text { Body mass })^{\wedge 0.304}\right)$, which is just slightly 199 longer than the $453 \mathrm{~mm}$ measured on OR39749 that lacked a distal metaphysis. The predictors 200 based on radial and metacarpal cross sectional dimensions offered much higher body mass 201 estimates, with averages of $1024 \mathrm{~kg}$ and $1107 \mathrm{~kg}$ respectively. In addition to employing 202 ontogenetic data to generate allometric equations, we also referred to previously published 203 interspecific studies (Anderson, Hall-Martin \& Russell, 1985; Roth, 1990; Scott, 1990; 204 Campione \& Evans, 2012). Interspecific equations tended to predict heavier body masses than 205 ontogenetic equations, especially so in the distal long bone samples.

\section{Predictions based on dental dimensions}

208 Four molars and two premolars were used for size predictions (Table 4), using equations developed by Damuth (1990). Body mass predictions based on tooth length (average $=577 \mathrm{~kg}$, 210 standard deviation $=155 \mathrm{~kg}$ ) tended to be smaller than the predictions based on tooth width 211 (average $=881 \mathrm{~kg}$, standard deviation $\left.=188 \mathrm{~kg}, t_{(27)}=4.83, p<0.01\right)$. Predictions from molar

212 length dimensions also tended to be lower than those from premolar lengths (average from molar 213 lengths $=473 \mathrm{~kg}$, average from premolar lengths $\left.=682 \mathrm{~kg}, t_{(9)}=-3.12, p<0.05\right)$. 
215

216

217

\section{Discussion}

\section{Vertebral identity of OR39747}

The anatomical identity of OR39747 was disputed by Lydekker (1885a). He showed that Falconer was in a habit of not counting the atlas and axis as cervical vertebrae - which often meant that the start of the numbering of vertebra commenced at the third or occasionally the second postcranial vertebra. Mammalian C3 to $\mathrm{C} 5$ forms a repetitive series and often does not have the distinguishing characteristics present in the other cervical vertebrae (Solounias, 1999). It is therefore indeed challenging to assign OR39747 to a specific vertebra. However, if we assume approximate similarity in shape between G. sivalensis and G. camelopardalis vertebrae, there are clues in the extent to which the cranial articular processes (Proc. articularis cranialis) extend beyond the body or centrum of the vertebra (Corpus vertebrae). In the G. camelopardalis C3, this process extends well beyond the cranial extremity of the vertebral body, but ends before or approximately at the same dorsoventral plane as the vertebral body in C4 and C5. Judging then by the extent of the articular processes of OR39747, it is a third, fourth or fifth cervical in decreasing order of likelihood. Falconer was therefore correct in assigning this vertebra as a third cervical, albeit fortuitously so.

\section{Ontogenetic and interspecific scaling models}

It is unusual although not unique to use ontogenetic allometry to predict an extinct animal's size. For instance, Roth (1990) proposed that smaller animals of a species with distinctive morphologies (be they juvenile or adult) may still be better analogues than other taxa, at least in some aspects. We believe that this view is warranted in the current study as no extant species has such an extreme shape as G. camelopardalis. Predicting fossil masses from interspecific 
equations are further complicated by the decision of which taxa to include in regressions. For example, it is not clear whether predictions generated from interspecific allometric data are more accurate when based on closely related taxa with similar locomotor habits (Runestad, 1994; Janis, Theodor \& Boisvert, 2002) or when using a wider sampling base (De Esteban-Trivigno, Mendoza \& De Renzi, 2008). Other factors that may influence precision of body mass predictions in interspecific studies are body mass estimations (instead of body mass measurements), small intrataxa sample sizes, and overrepresentation of animals of one sex or of exaggerated proportions. To overcome these problems, we investigated which ontogenetic scaling parameters, if any, might be suitable and robust enough for predictions amongst extant Giraffidae. It is possible that giraffe ontogenetic equations are also acceptable for comparison not just amongst the Giraffidae but amongst, for example, extant camelids with similar gaits. However, okapis were considered as an adequate reference in this case as they are closest to giraffes phylogenetically and because the ontogenetic scaling of their long bones scales differently to other cetartiodactyla (Kilbourne \& Makovicky, 2012).

Ontogenetic scaling and interspecific scaling exponents are generally not interchangeable (Gould, 1966; Pélabon et al., 2013); in this case it is dependent on the assumption that $G$. sivalensis had a similar body plan as juvenile extant giraffes. We thus found it appropriate, where possible, to test both ontogenetic and interspecific curves to infer proportions of G. sivalensis, but realised that neither of these methods may be appropriate for each and every dimension measured. 
Badlangana, Adams \& Manger (2009) presented interspecific predictions for vertebral neck

length based on vertebral body length. Using their data (presented in Table 1 of Badlangana, Adams \& Manger, 2009), we could estimate G. sivalensis C2-C7 vertebral neck length as 1150 $\mathrm{mm}$ (Table 6), slightly shorter (45 $\mathrm{mm}$ or $4 \%$ ) than vertebral neck length calculated from our ontogenetic data. There are therefore reasonable grounds to believe that our estimated neck length based on ontogenetic data is valid, or at least close to interspecific curves. Further support for this rationale can be seen where the G. camelopardalis ontogenetic curve gives appropriate predictions for vertebral neck length in both the extant giraffe and okapi (Figure 5). Extant adult giraffes have an average external neck length of about $2013 \mathrm{~mm}$ in males (1000 $\mathrm{kg}$ and above) and $1832 \mathrm{~mm}$ in females (800 kg and above) (Mitchell, van Sittert \& Skinner, 2009). Assuming the same body plan for G. sivalensis as for G. camelopardalis, then G. sivalensis had around 350 $\mathrm{mm}(20 \%)$ to $550 \mathrm{~mm}(27 \%)$ shorter necks than modern giraffes, depending on whether OR39747 came from a female or male animal. This is a slightly longer neck length than Falconer \& Cautley's (1843) estimated neck length for G. sivalensis, which is approximately a third shorter than extant giraffes.

\section{Body mass}

The body mass predictions for G. sivalensis are wide (Figure 6). Possible reasons for the large range of predictions are that certain fossils were erroneously attributed to G. sivalensis and/or that certain specimens and allometric equations are inadequate for body mass predictions. Before decisions could be made regarding the validity of attributing a fossil to G. sivalensis, we ascertained the equations that were robust enough to predict body mass accurately across species. 


\section{Vertebra OR39747 body mass estimates}

It is unconventional to use vertebrae as proxies for body mass, although due to the lack of other samples it has been done before (see for instance Taylor, 2007; Taylor \& Naish, 2007). As OR39747 is the holotype, it necessitates that body mass estimates are made from it if other Giraffa spp. specimens are to be attributed to it. Although vertebral body length has higher $\mathrm{R}^{2}$ values than cross sectional vertebral properties (Table 7, van Sittert, Skinner \& Mitchell, 2010), cross sectional properties are still preferable predictors of body mass in this case. The first reason is that $\mathrm{R}^{2}$ value is inferior to percent prediction error $(\% \mathrm{PE})$ and percent standard error of the estimate when assessing reliability of body mass predictions through regressions (Smith, 1984).

Secondly, vertebral cross sectional properties are subjected to the stresses and strains within the neck (Slijper, 1946) and therefore are a much better indicator of head and neck mass and by implication body mass. Conversely, vertebral body length is influenced by factors other than body mass such as the number of vertebrae in an anatomical area (compare birds and mammals' cervical region) or the lifestyle of the animal. We found caudal vertebral height (dorsoventral diameter) to have the lowest $\% \mathrm{PE}(25 \%$ and $17 \%)$ when predicting body mass in both extant giraffes and okapis respectively (Table 7, Figure 7), and therefore considered this dimension to be most robust for body mass predictions across giraffids. There are no other published interspecific regression equations using vertebral dimensions for the prediction of body mass in ungulates of which we are aware. The caudal vertebral height predicts a body mass of $390 \mathrm{~kg}$ in G. sivalensis. Interestingly, the average body mass prediction from the remaining vertebral regression equations ( $\mathrm{C} 3$ vertebral body length, cranial height, cranial width and caudal width, Table 7) is fairly similar - $368 \mathrm{~kg}$. The only body mass prediction to fall outside the $95 \%$ 
confidence interval based on all vertebral dimensions including vertebral height (373 $\mathrm{kg} \pm 119$

$\mathrm{kg}$ ) is vertebral body length, predicting a mass of $575 \mathrm{~kg}$.

Nevertheless, the body mass prediction from caudal vertebral height could be either an over or underestimate. Considering it as an overestimate would mean that this animal had a relatively heavy neck and head complex but a slender or lightweight body. This is unlikely as a larger head and neck complex is unsupportable unless accompanied by a larger total body size (Taylor \& Wedel, 2013). Conversely an underestimate would mean a slender neck and head complex but a relatively stocky body. This is a more plausible scenario and if indeed it is the case, it might explain the discrepancy between vertebral and dental body mass predictions when compared to those of limb bones.

\section{Limb bone body mass estimates}

Interspecific long bone cross sectional properties, although probably more closely related to body mass than any other variable, have nevertheless been found to be poor predictors of body mass in giraffes and in some cases, okapis (McMahon, 1975; Anderson, Hall-Martin \& Russell, 1985; Scott, 1990; Janis, Theodor \& Boisvert, 2002), although it should be noted that a recent interspecific study has shown giraffes to be more amenable to interspecific equation predictions (Campione \& Evans, 2012). Similarly, we found higher prediction errors with interspecific equations compared to G. camelopardalis ontogenetic curves, with a 5\% prediction error based on humeral ontogenetic data (Figure 7). Errors were inflated when using more distal bones. Therefore, the most appropriate long bone variable useful for G. sivalensis body mass determination is very likely humeral cross sectional properties, using our ontogenetic $G$. camelopardalis sample. 
The average body mass estimated from humeral ontogenetic analysis is $732 \mathrm{~kg}$. Interestingly, this body mass is about $150 \mathrm{~kg}$ more than would be indicated by a G. camelopardalis of similar neck length, and $342 \mathrm{~kg}$ more than the mass predicted from OR39747 cross sectional properties. This could mean that either the humeral fossil specimens were incorrectly assigned to $G$. sivalensis, that G. sivalensis had a relatively stockier body and thinner neck than $G$. camelopardalis or that the holotype vertebra came from a female and the humeral specimens from large males.

Unfortunately, none of the other long bone dimensions seem to be reliable predictors of body mass across extant giraffids. The best non-humerus candidate using interspecific scaling seems to be the radius transverse diameter with a $43 \%$ and $11 \%$ prediction error in okapis and giraffes respectively. This dimension predicts that the specimen belonged to an animal of approximately $1238 \mathrm{~kg}$, which suggests this animal might have been heavier than G. sivalensis. There are no interspecific equations for metacarpi that we could find, and therefore we could only rely on ontogenetic equations. Yet, similar to the radial prediction, the metacarpal transverse diameter predicts a body mass of 1165 with around $20 \%$ prediction error. The inflated prediction errors could be because humeri and femora are generally more suitable for body mass predictions than more distal bones, especially in giraffes (McMahon, 1975). It is also possible that the fossil long bones were incorrectly assigned to G. sivalensis and perhaps belonged to another similar species existing at the same time and location. 
There have been numerous dental specimens ascribed to G. sivalensis (Supplementary Table 1). Unfortunately, not all of these specimens are from the same locality and are probably from different stratigraphic zones. Subsequently, there appeared to be uncertainty regarding the correct species allocation of these fossils (see especially Lydekker, 1876). A discussion on the morphology and correct species classification of teeth specimens assigned to G. sivalensis were not considered as part of this study, and we therefore used only those teeth mentioned by Falconer and Cautley (1843). These specimens were originally assigned to the species G. affinis a classification later abandoned by Falconer himself and also disputed by Lydekker (1883), who re-assigned the fossils to G. sivalensis. As the specimens originated from the same area and strata as the holotype OR39747, which is the Pliocene of the Siwaliks (Lydekker, 1885a), we believe it reasonable to consider them as truly G. sivalensis teeth until further evidence emerges.

Molar length measurements are more reliable indicators of body mass than molar width or area (Damuth, 1990; Fortelius, 1990; Janis, 1990). Furthermore, Janis (1990) found that premolar row length are poorer correlates than molar row length. Molar lengths predict an animal within the range of $288 \mathrm{~kg}$ to $673 \mathrm{~kg}$, which is similar to OR39747's caudal vertebral height body mass prediction of $390 \mathrm{~kg}$.

\section{Combined size estimates}

Lydekker's (1885a) suggestion that OR39747 belonged to a small individual could have meant that the animal was still immature, that the animal was a relatively small individual of the species or that the species itself was small within the genus. It is unlikely that Lydekker meant an immature animal as the fusion of the epiphyses to the body of the vertebra is complete and clear 
definitions of bony ridges and muscular depressions indicate a mature animal (Falconer \& Cautley, 1843). Lydekker might have based his idea of a small individual on two larger vertebrae assigned to G. sivalensis - a proximal part of a 'third' and distal part of a 'fourth' cervical, OR39746 and OR39748 respectively (Lydekker, 1885a, Table S1). Unfortunately, these vertebrae were not locatable within the Siwalik collection at the time of this study (Personal communication, P Brewer, Curator of fossil mammals, Natural History Museum, 2013), and we subsequently could not measure them. Nevertheless, Falconer (1845) reported OR39748 to be 2.1 inch $(53.3 \mathrm{~mm})$ in height and width at the caudal extremity, which is only $0.2 \mathrm{~mm}$ greater and $0.1 \mathrm{~mm}$ less than our respective measurements of OR39747 (Table 2). Based on ontogenetic allometry for caudal vertebral body height, OR39748 came from an animal weighing $394 \mathrm{~kg}$ or $277 \mathrm{~kg}$, depending on whether it was a C3 or C4 vertebra respectively (Table 7). The animal from which the holotype vertebrae originated was therefore also not relatively small compared to the size estimated from specimen OR39748. It is possible though, especially considering body mass estimates from the humerus, that there might have been sexual size dimorphism present in G. sivalensis. If that is indeed the case, OR39747 and OR39748 would have been females about half the size of fully grown male animals, a possibility also supported by the fossil teeth considered in body mass estimates.

\section{Conclusion}

Our considered opinion is that the G. sivalensis, from which the holotype cervical vertebra originated weighed approximately $400 \mathrm{~kg}$, had a neck length of about $1.47 \mathrm{~m}$ and a reaching height of $3.9 \mathrm{~m}$. There is a possibility that it displayed sexual dimorphism, in which case male animals would have been a little less than twice the size of females and both would have had a 
396 similar morphology. If sexual dimorphism was not present and all bones were correctly

397 attributed to this species, then the animal had a slender neck with a relatively stocky body, a

398 shape that is not unrealistic to imagine. 
References:

Akhtar M, Sarwar M, Saeed M, Khan AA. 1991. Vertical distribution of Siwalik giraffids. Acta Scientia 1:145-152.

Anderson JF, Hall-Martin A, Russell DA. 1985. Long-bone circumference and weight in mammals, birds and dinosaurs. Journal of Zoology 207:53-61.

Badam GL. 1979. Pleistocene Fauna of India with special reference to the Siwaliks. Pune, India: Deccan College Postgraduate and Research Institute.

Badlangana NL, Adams JW, Manger PR. 2009. The giraffe (Giraffa camelopardalis) cervical vertebral column: a heuristic example in understanding evolutionary processes? Zoological Journal of the Linnean Society 155:736-757.

Bhatti ZH. 2004. Taxonomy, evolutionary history and biogeography of the Siwalik giraffids. $\mathrm{PhD}$ Thesis. Lahore: University of the Punjab.

Campione NE, Evans DC. 2012. A universal scaling relationship between body mass and proximal limb bone dimensions in quadrupedal terrestrial tetrapods. BMC Biology 10:60.

Cautley PT. 1838. Note on a fossil ruminant genus allied to Giraffidae, in the Siwalik Hills. Journal of the Asiatic Society of Bengal 7:658-660.

Cawley GC, Janacek GJ. 2010. On allometric equations for predicting body mass of dinosaurs. Journal of Zoology 280:355-361.

Damuth J. 1990. Problems in estimating body masses of archaic ungulates using dental measurements. In: Body Size in Mammalian Paleobiology: Estimation and Biological Implications. Cambridge: Cambridge University Press, 229-253.

De Esteban-Trivigno S, Mendoza M, De Renzi M. 2008. Body mass estimation in Xenarthra: a predictive equation suitable for all quadrupedal terrestrial placentals? Journal of morphology 269:1276-1293.

Falconer H. 1845. Description of some fossil remains of Dinotherium, Giraffe, and other mammalia, from the Gulf of Cambay, western coast of India, chiefly from the collection presented by Captain Fulljames, of the Bombay Engineers, to the Museum of the Geological Society. Quarterly Journal of the Geological Society 1:356-372.

Falconer H. 1868. Description by Dr. Falconer of fossil remains of Giraffe in the museum of Asiatic Society of Bengal. In: Murchison C ed. Palaeontological memoirs and notes of the late Hugh Falconer. Fauna Antiqua Sivalensis. London: R. Hardwicke, 206-207. 
430 Falconer H, Cautley PT. 1843. On some fossil remains of Anoplotherium and Giraffe, from the Sewalik Hills, in the north of India. Proceedings of the Geological Society of London 4:235-249.

Falconer H, Murchison C. 1867. Description of the plates of the Fauna Antiqua Sivalensis.

433 London: R. Hardwicke.

434 Fortelius M. 1990. Problems with sing fossil teeth to estimate body sizes of extinct mammals. In:

Damuth J, MacFadden BJ eds. Body Size in Mammalian Paleobiology: Estimation and Biological Implications. Cambridge: Cambridge University Press,.

Gaur R, Vasishat N, Chopra SRK. 1985. New and some additional fossil mammals from the Siwaliks exposed at Nurpur, Kangra district, H.P. Journal of the palaeontological society of India 30:42-48.

Glazier DS. 2013. Log-transformation is useful for examining proportional relationships in allometric scaling. Journal of theoretical biology 334:200-203.

Gould SJ. 1966. Allometry and size in ontogeny and phylogeny. Biological reviews of the Cambridge Philosophical Society 41:587-640.

Huxley JS. 1932. Problems of relative growth. New York: The dial press.

International Committee on, Veterinary Gross Anatomical Nomenclature. 2012. Nomina Anatomica Veterinaria (N.A.V.).

Janis CM. 1990. Correlation of cranial and dental variables with body size in ungulates and macropodoids. In: Body size in mammalian paleobiology: estimation and biological implications. Cambridge: Cambridge University Press,.

Janis CM, Theodor JM, Boisvert B. 2002. Locomotor evolution in camels revisited: a quantitative analysis of pedal anatomy and the acquisition of the pacing gait. Journal of vertebrate paleontology 22:110-121.

Kilbourne BM, Makovicky PJ. 2012. Postnatal long bone growth in terrestrial placental mammals: Allometry, life history, and organismal traits. Journal of Morphology 273:1111-1126.

Lindsey SL, Bennett CL. 1999. The Okapi: Mysterious Animal of Congo-Zaire. Austin: University of Texas Press.

Lydekker R. 1876. Notes on the fossil mammalian faunae of India and Burma. In: Records of the Geological Survey of India. London: Trübner and Co., 86-105.

Lydekker R. 1878. Notices of Siwalik Mammals. In: Records of the Geological Survey of India. London: Trübner and Co., 83-95. 
Lydekker R. 1883. Indian Tertiary and post Tertiary vertebrata: Siwalik Camelopardalidae. In: Memoirs of the Geological survey of India: Palaeontologica Indica, Being Figures and Descriptions of the Organic Remains Procured During the Progress of the Geological Survey of India. Calcutta: Geological survey of India, by order of the Governor-General of India, 99-142.

Lydekker R. 1885a. Catalogue of fossil mammalia. Part ii. Containing the order ungulata, suborder Artiodactyla. London: Taylor and Francis. Printed by order of the Trustees.

Lydekker R. 1885b. Catalogue of the remains of Siwalik Vertebrata contained in the Geological Department of the Indian Museum, Calcutta. Printed by the Superintendent of Government Printing, India.

Matthew WD. 1929. Critical observations upon Siwalik mammals (exclusive of Proboscidea). Bulletin of the American Museum of Natural History 56:437-560.

McMahon TA. 1975. Allometry and Biomechanics: Limb Bones in Adult Ungulates. The American Naturalist 109:547-563.

Mitchell G, van Sittert SJ, Skinner JD. 2009. Sexual selection is not the origin of long necks in giraffes. Journal of Zoology (London) 278:281-286.

Mitchell G, Skinner JD. 2003. On the origin, evolution and phylogeny of giraffes Giraffa camelopardalis. Transactions of the Royal Society of South Africa 58:51-73.

Murchison C. (ed.) 1868. Palceontological Memoirs and Notes of the Late Hugh Falconer: With a Biographical Sketch of the Author. London: R. Hardwicke.

Nanda AC. 2002. Upper Siwalik mammalian faunas of India and associated events. Journal of Asian Earth Sciences 21:47-58.

Nanda AC. 2008. Comments on the Pinjor Mammalian Fauna of the Siwalik Group in relation to the post-Siwalik faunas of Peninsular India and Indo-Gangetic Plain. Quaternary International 192:6-13.

Packard GC. 2013. Is logarithmic transformation necessary in allometry? Biological Journal of the Linnean Society 109:476-486.

Packard GC, Boardman TJ, Birchard GF. 2009. Allometric equations for predicting body mass of dinosaurs. Journal of Zoology 279:102-110.

Packard GC, Boardman TJ, Birchard GF. 2010. Allometric equations for predicting body mass of dinosaurs: a comment on Cawley \& Janacek (2010). Journal of Zoology 282:221-222.

Pélabon C, Bolstad GH, Egset CK, Cheverud JM, Pavlicev M, Rosenqvist G. 2013. On the relationship between ontogenetic and static allometry. The American naturalist 181:195-212. 
Roth VL. 1990. Insular dwarf elephants: a case study in body mass estimation and ecological inference. In: Damuth JD, MacFadden BJ eds. Body Size in Mammalian Paleobiology: Estimation and Biological Implications. Cambridge: Cambridge University Press, 151-179.

Runestad JA. 1994. Humeral and Femoral Diaphyseal Cross-sectional Geometry and Articular Dimensions in Prosimii and Platyrrhini (primates) with Application for Reconstruction of Body Mass and Locomotor Behavior in Adapidae (primates: Eocene). Johns Hopkins University.

Van Schalkwyk OL. 2004. Bone density and calcium and phosphorous content of the giraffe (Giraffa camelopardalis) and African buffalo (Syncerus caffer) skeletons. Pretoria: University of Pretoria.

Van Schalkwyk OL, Skinner JD, Mitchell G. 2004. A comparison of the bone density and morphology of giraffe (Giraffa camelopardalis) and buffalo (Syncerus caffer) skeletons. Journal of zoology 264:307-315.

Scott K. 1990. Postcranial dimensions of ungulates as predictors of body mass. In: Damuth J, MacFadden BJ eds. Body size in mammalian paleobiology. Cambridge: Cambridge University Press,.

Van Sittert SJ, Skinner JD, Mitchell G. 2010. From fetus to adult - an allometric analysis of the giraffe vertebral column. Journal of Experimental Zoology Part B Molecular and Developmental Evolution 314B:469-479.

Van Sittert S, Skinner J, Mitchell G. 2015. Scaling of the appendicular skeleton of the giraffe (Giraffa camelopardalis). Journal of Morphology 276:503-516.

Slijper EJ. 1946. Comparative biologic-anatomical investigations on the vertebral column and spinal musculature of mammals. Verhandelingen der Koninklijke Nederlandsche Akademie van Wetenschappen Afdeling Natuurkunde 42:1-128.

Smith RJ. 1984. Allometric scaling in comparative biology: problems of concept and method. American Journal of Physiology-Regulatory, Integrative and Comparative Physiology 246:R152-R160.

Solounias N. 1999. The remarkable anatomy of the giraffe's neck. Journal of Zoology (London) 247:257-268.

Spamer EE, Daeschler E, Vostreys-Shapiro LG. 1995. A Study of Fossil Vertebrate Types in the Academy of Natural Sciences of Philadelphia: Taxonomic, Systematic, and Historical Perspectives. Academy of Natural Sciences.

Stuart C, Stuart M. 2006. Field Guide to Larger Mammals of Africa. Cape Town: Struik Publishers. 
526 Taylor MP. 2007.Xenoposeidon week, day 4: the question everyone is asking ... how big was it?

527 Available at http://svpow.com/2007/1 1/18/xenoposeidon-week-day-4-the-question-everyone-is-

528 asking-how-big-was-it/ (accessed May 27, 2015).

529 Taylor MP, Naish D. 2007. An Unusual New Neosauropod Dinosaur from the Lower Cretaceous 530 Hastings Beds Group of East Sussex, England. Palaeontology 50:1547-1564.

531 Taylor MP, Wedel MJ. 2013. Why sauropods had long necks; and why giraffes have short necks. 532 PeerJ 1:e36.

533 Van Valkenburgh B. 1990. Skeletal and dental predictors of body mass in carnivores. In: Body 534 size in mammalian paleobiology. Cambridge: Cambridge University Press.

535 Warton DI, Wright IJ, Falster DS, Westoby M. 2006. Bivariate line-fitting methods for 536 allometry. Biological reviews of the Cambridge Philosophical Society 81:259-291. 
1

A map indicating the probable vicinity of $G$. sivalensis fossil discoveries.

The marker indicates the location of the Shivalik Fossil Park in the Siwalik Hills, a subHimalayan mountain range. This is most probably the area 'west to the river Jumna' (currently Yamuna River) to which Falconer and Cautley (1843) referred. Map data: AutoNavi, Google. 


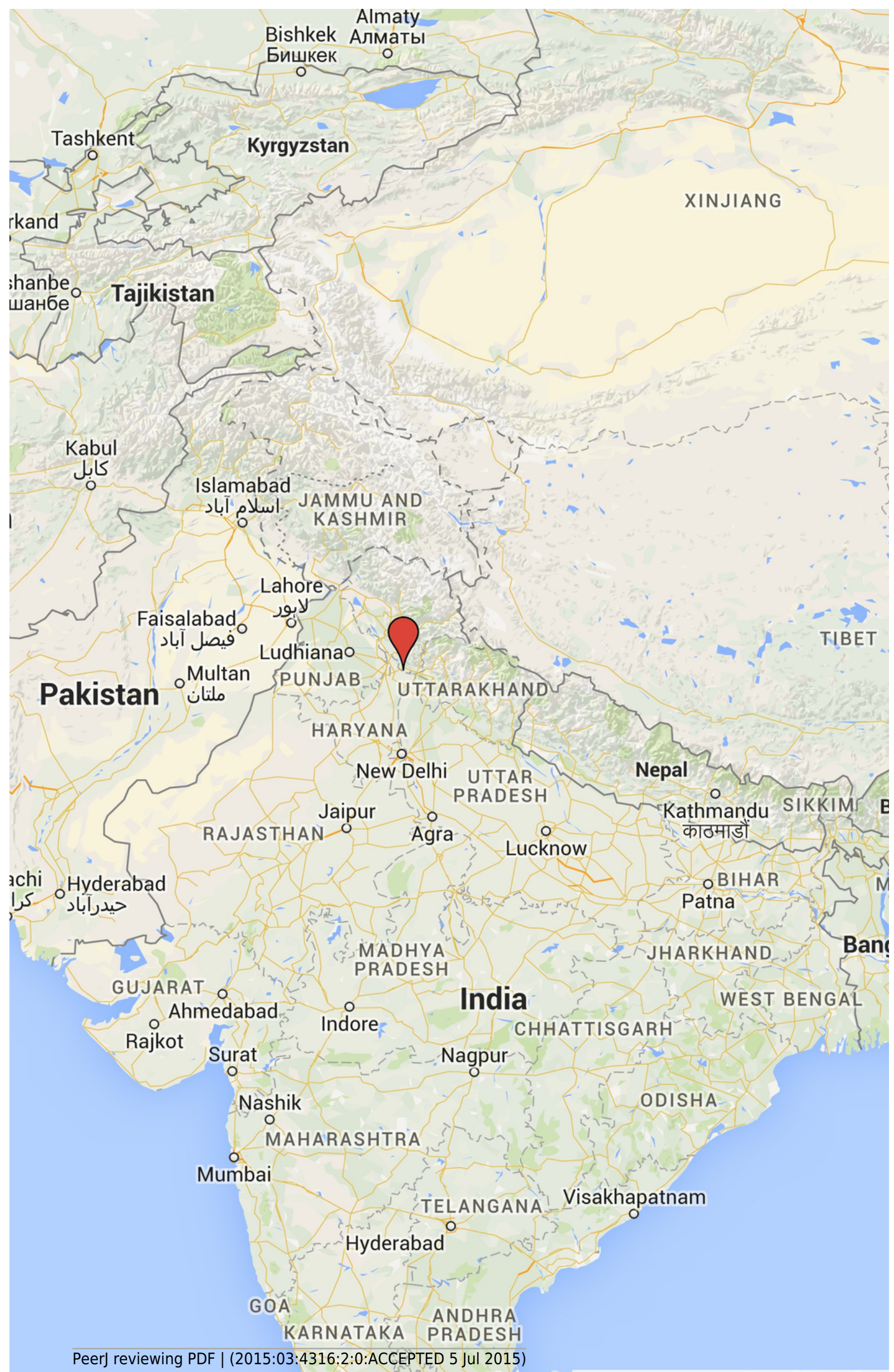


2

Giraffa sivalensis holotype, specimen OR39747.

Presented, from left to right, in left lateral (A), right lateral (B), cranial (C) and caudal (D) views. On left lateral view the line indicates the landmarks for the vertebral body length (L) measurement. On cranial and caudal views the vertical lines indicate the height (dorsoventral, DV) while the horizontal lines indicate the width (transverse, T) measurements.

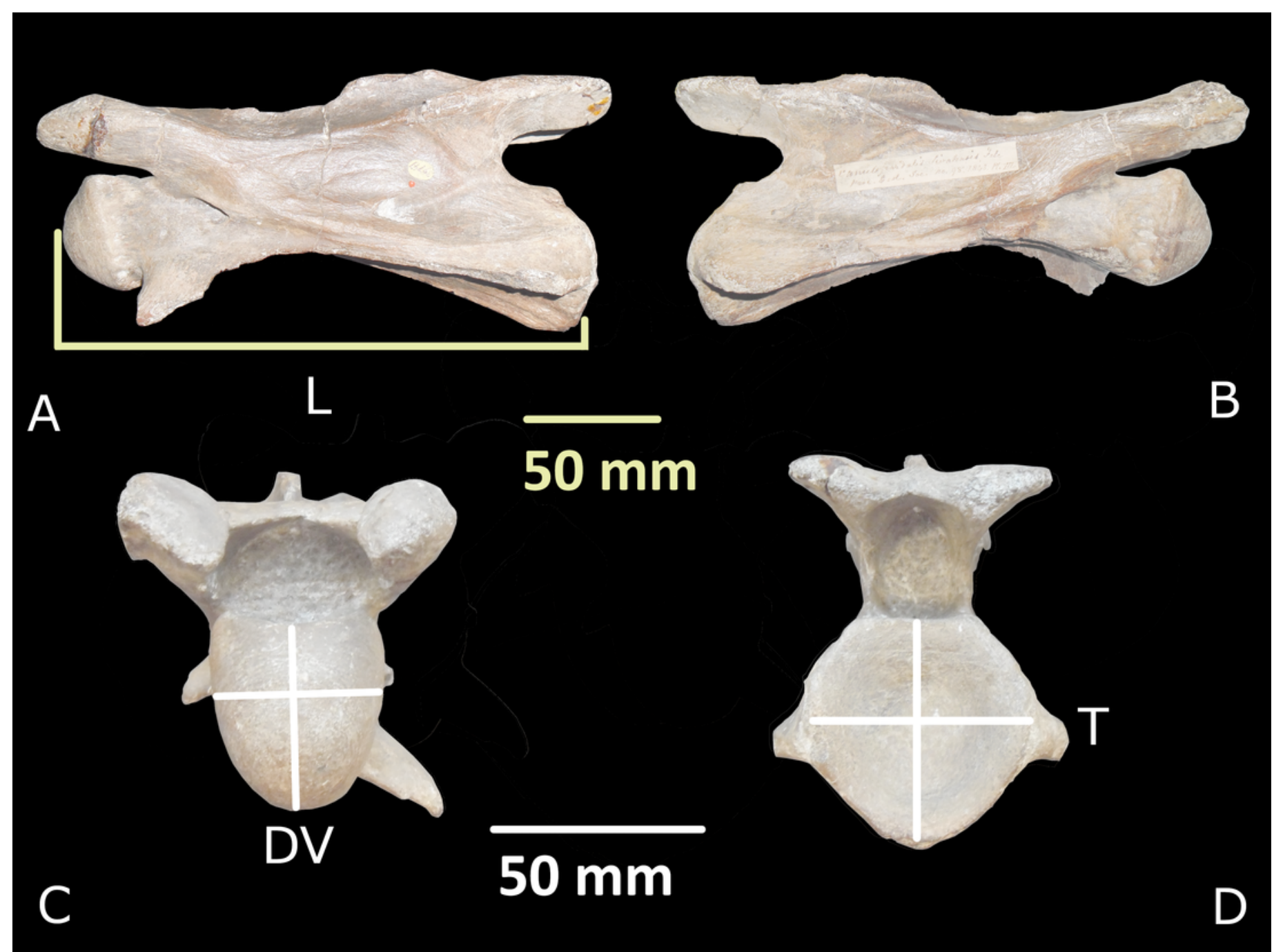


3

Specimen OR39749.

This image represents different views of a right humerus that has been assigned to $G$. sivalensis. The different views are not to scale; where only distal parts of the bone are shown, these have been enlarged relative to images of the specimen in toto. The scale bar indicates $50 \mathrm{~mm}$ and pertains to the lateral view only.

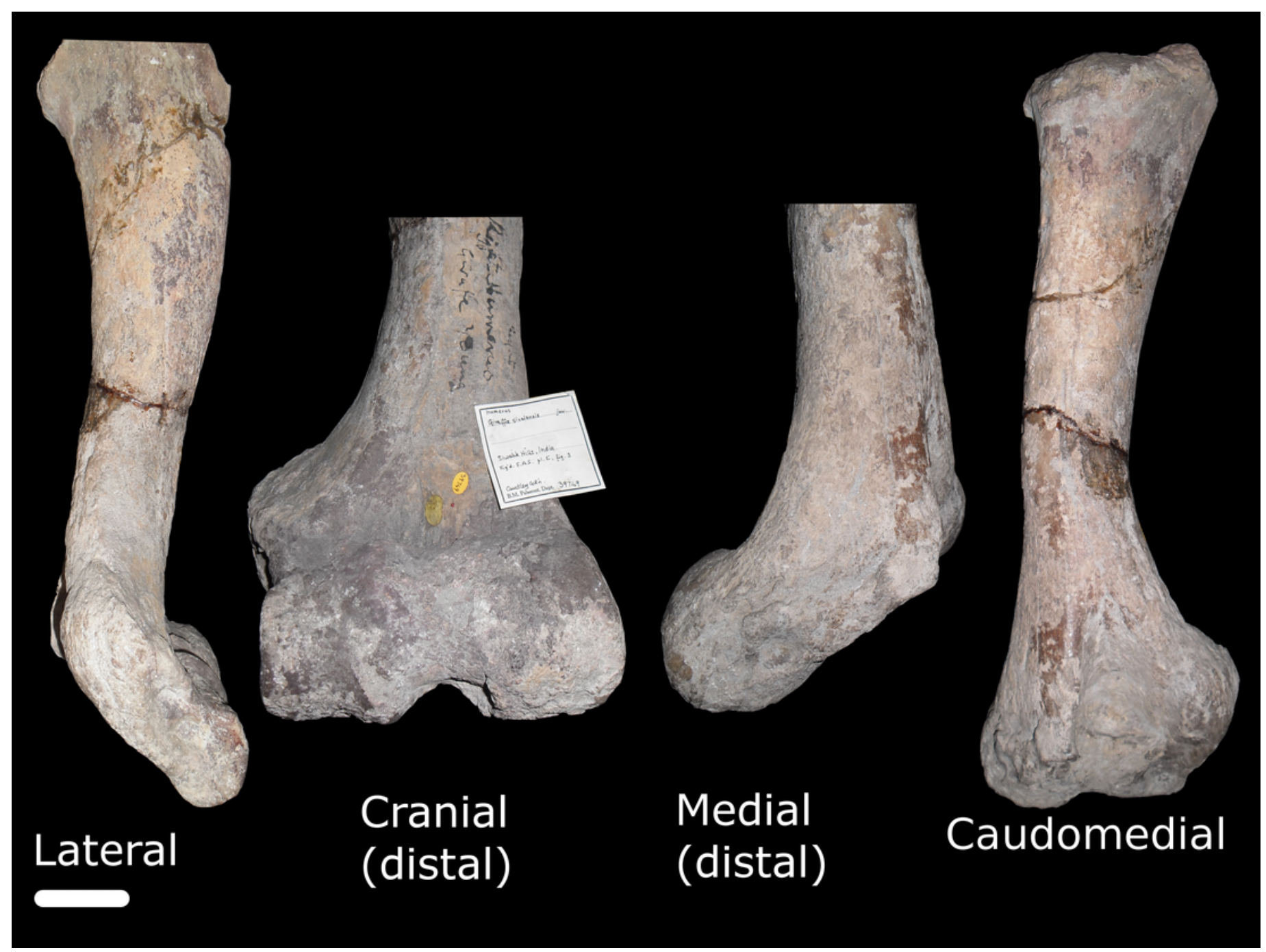


4

Specimen OR17136.

This represents different views of the proximal part of a left humerus that has been assigned to $G$. sivalensis. The scale bar indicates $50 \mathrm{~mm}$ and pertains to the lateral view only as the different views are not drawn to scale.

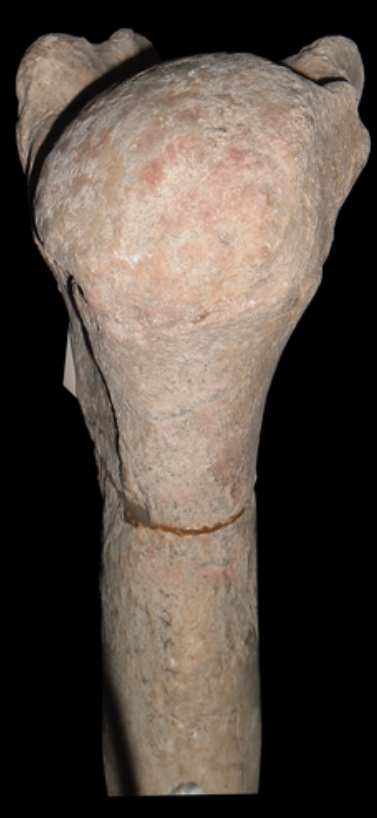

Caudal

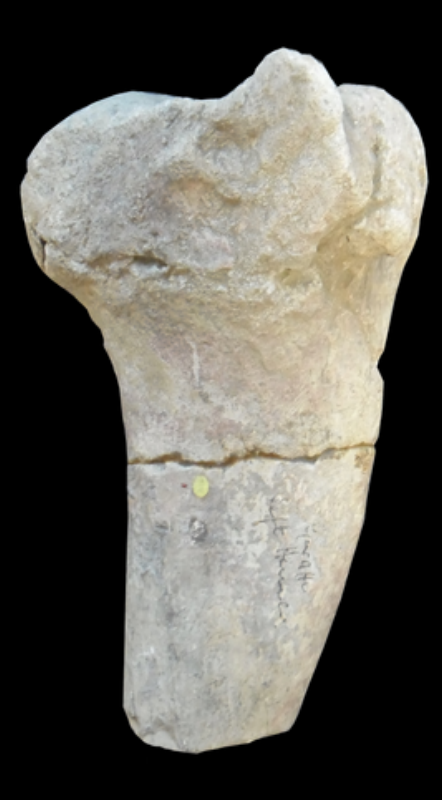

Medial

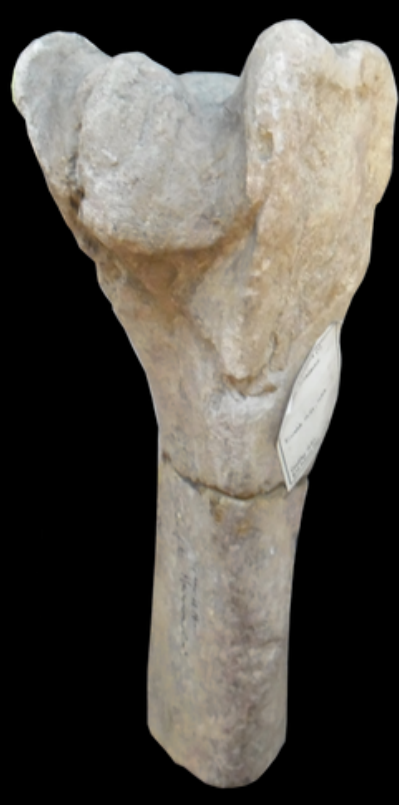

Craniolateral

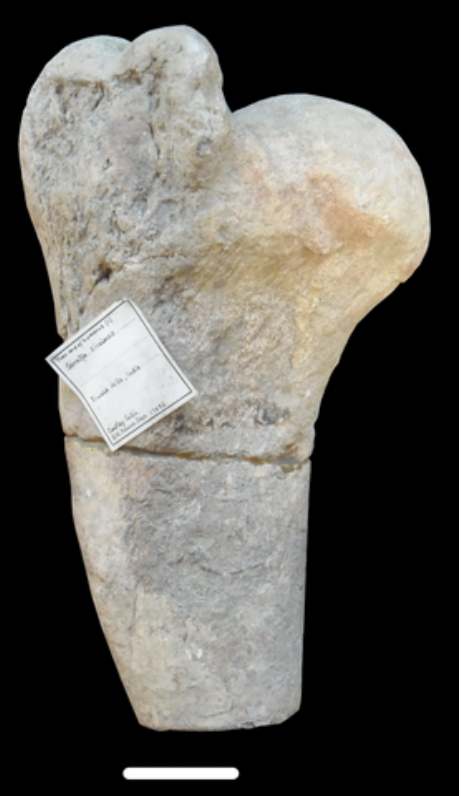

Lateral 


\section{5}

The relationship between neck length and $\mathrm{C} 3$ vertebral length throughout ontogeny in giraffes and okapis.

A regression line is based on the giraffe ontogenetic series and is extrapolated to the okapi range. The use of a regression line for ontogenetic and phylogenetic allometry seems to be appropriate in this case, supporting the use of a giraffe ontogenetic regression line to predict a neck length value for $G$. sivalensis.

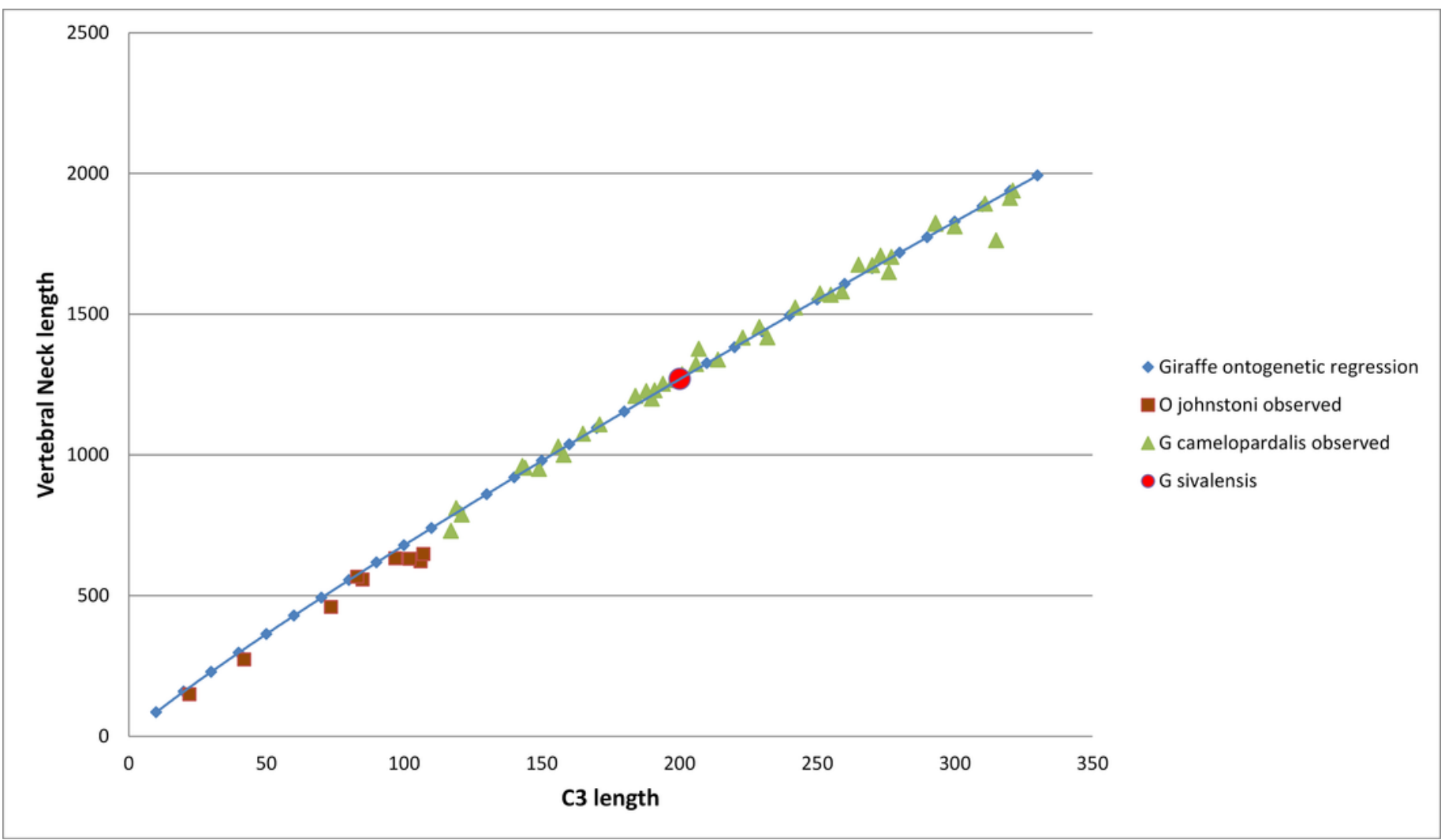




\section{6}

Body mass predictions for $G$. sivalensis based on various fossil specimens.

The labels are divided into predictions from vertebral dimensions (diamond shapes), humeral dimensions (squares), radial dimensions (circles) and metacarpal dimensions (crosses). The humeral and radial dimensions are further subdivided into those originating from ontogenetic allometric equations (red and purple, respectively) and those from interspecific equations (green and orange, respectively). Note that the interspecific predictions generally provide heavier estimates of body mass than predictions based on ontogenetic data. Furthermore, the distal bones tend to predict higher values than the proximal (humerus) bone predictions. Vertebral predictions give the lightest body mass estimates. Abbreviations: Vert: Vertebral body; H: Humerus; R: Radius; Mc: Metacarpus; Cr: Cranial; Cd: Caudal; CrTr: Cranial Transverse Dimension; CrDv: Cranial Dorsoventral Diameter; CdTr: Caudal Transverse Diameter; Cddv: Caudal Dorsoventral Diameter; Crcd: Craniocaudal Midshaft Diameter; Tr: Transverse Midshaft Diameter; Circ: Midshaft Circumference; ont: ontogenetic sample; inters: interspecific sample; Sc, (Scott, 1990); Ro, (Roth, 1990); An, (Anderson, Hall-Martin \& Russell, 1985) 


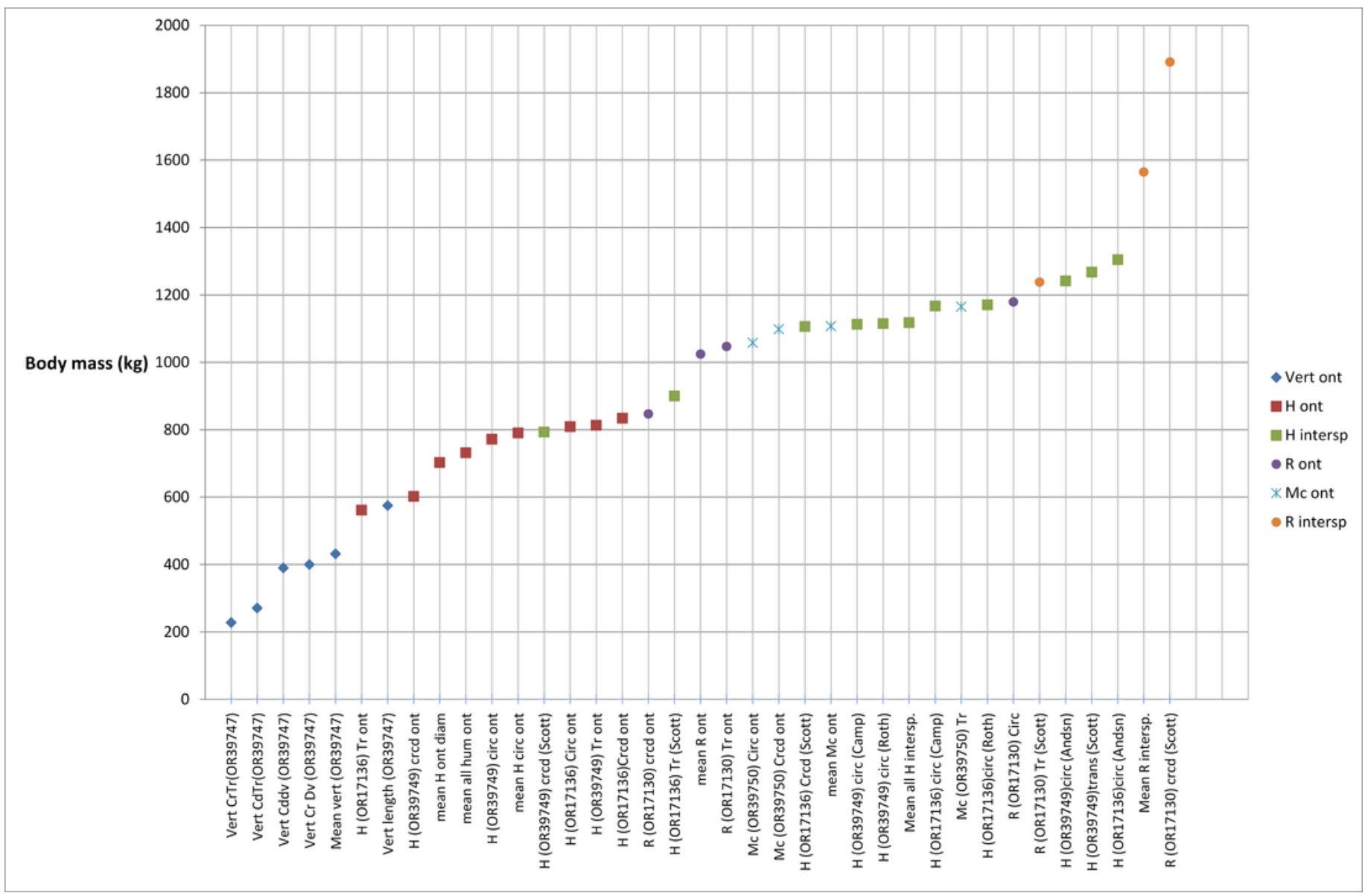


7

The body mass prediction errors (absolute values) associated with various dimensions in Okapia johnstoni and Giraffa camelopardalis.

Of the available regressions and variables measured, it would appear that humeral circumference and craniocaudal diameter (using G. camelopardalis ontogenetic regression) is best suited for body mass predictions, both in giraffes and okapis, and therefore also likely to be useful for body mass predictions in G. sivalensis. Vertebral caudal dorsoventral diameter represents an acceptable variable should estimates only be based on the holotype, with prediction errors of $17 \%$ and $25 \%$ in giraffes and okapis respectively. Different shapes indicate different bones used for body mass predictions. Note that for clarity of the graph, the maximum indicated prediction error is $100 \%$. Abbreviations: Oj: Okapia johnstoni; Gc: Giraffa camelopardalis; P.E: Prediction Error; other abbreviations as listed for Figure 2.

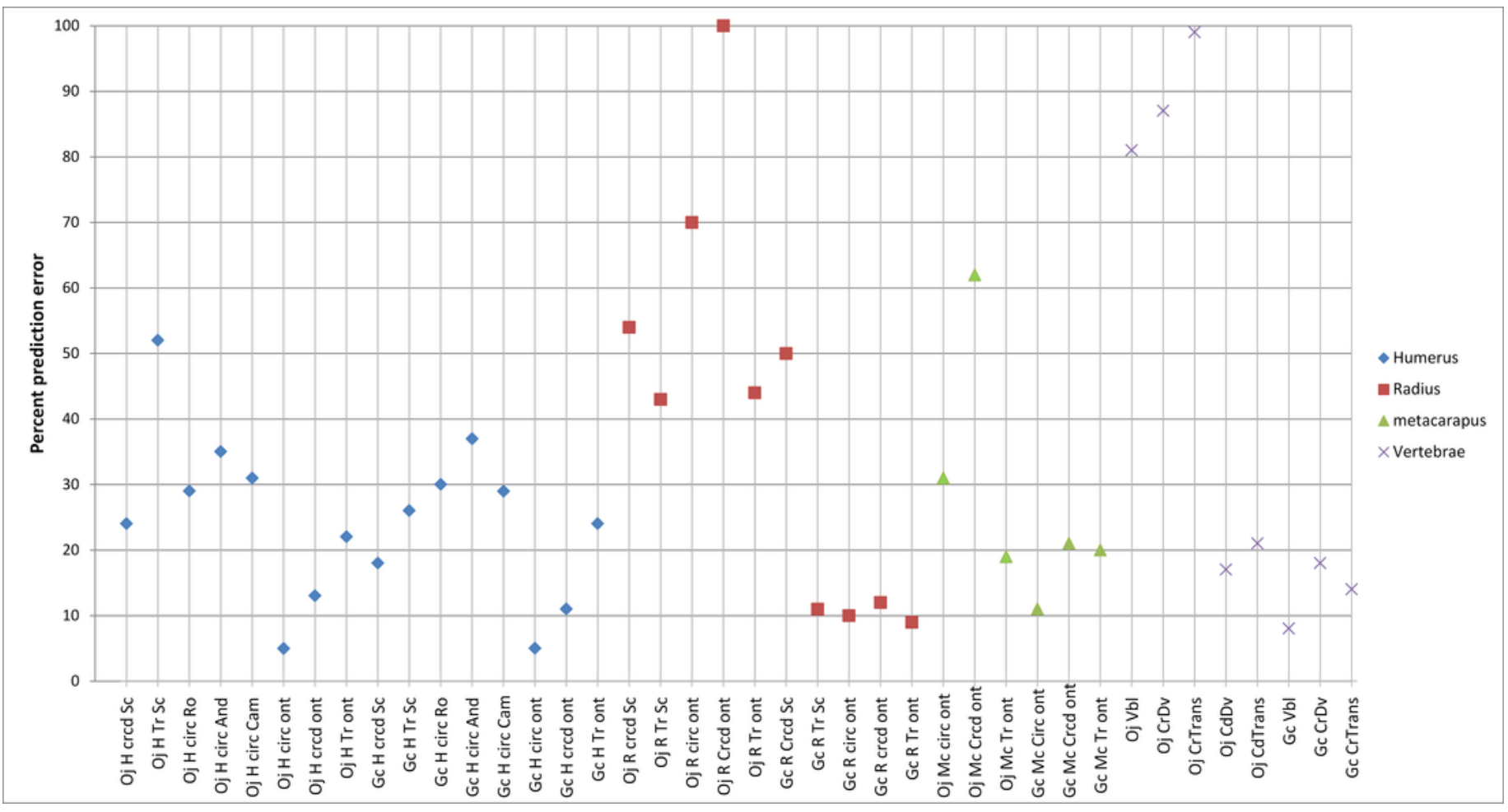




\section{Table $\mathbf{1}$ (on next page)}

Previous size estimates of $G$. sivalensis 


\begin{tabular}{|c|c|c|}
\hline Size estimate & Author & Relevant specimens/ comments \\
\hline $\begin{array}{l}\text { 'One third shorter' with a neck } \\
\text { 'one tenth more slender' as } \\
\text { extant giraffes. }\end{array}$ & $\begin{array}{l}\text { Falconer \& Cautley, 1843; } \\
\text { Lydekker, } 1876 \text { (p.105) }\end{array}$ & Holotype vertebra, OR39747 \\
\hline $\begin{array}{l}\text { Large species but smaller than } \\
\text { extant giraffes. }\end{array}$ & Bhatti, 2004, p. 155 & No specimen referred to. \\
\hline $\begin{array}{l}\text { Of comparable size to modern } \\
\text { giraffes. }\end{array}$ & Bhatti, 2004, p.225 & No specimen referred to. \\
\hline $\begin{array}{l}\text { Similar head size to extant } \\
\text { giraffes but with a shorter neck. }\end{array}$ & Lydekker, 1876, p.105 & $\begin{array}{l}\text { OR39747. Lydekker noted that } \\
\text { the areas of the zygoapohyses } \\
\text { are 'considerably larger' than in } \\
\text { those of extant giraffes, making } \\
\text { the neck 'at least equally } \\
\text { strong' as that that of extant } \\
\text { giraffes. The larger cranial and } \\
\text { caudal articular surfaces were } \\
\text { also noted by Falconer and } \\
\text { Cautley (1843). }\end{array}$ \\
\hline Similar in size to extant giraffes. & Lydekker, 1883 & $\begin{array}{l}\text { Cervical vertebra similar in size } \\
\text { as that of G. camelopardalis. } \\
\text { Referring to an imperfect 'first' } \\
\text { cervical vertebra, later } \\
\text { catalogued as a 'third' cervical, } \\
\text { BM39746 (Lydekker, 1885a). }\end{array}$ \\
\hline $\begin{array}{l}\text { Slightly larger than extant } \\
\text { giraffes. }\end{array}$ & Murchison, 1868, P207 & $\begin{array}{l}\text { Right humerus. Museum of the } \\
\text { Asiatic Society of Bengal no 43, } \\
\text { Natural History Museum no } \\
\text { 39749. Exact form to that of } \\
\text { extant giraffes, but a little } \\
\text { larger (Falconer, 1868). } \\
\text { Lydekker (1885a) however } \\
\text { mentioned that this fossil bone } \\
\text { originated from a 'small } \\
\text { individual'. }\end{array}$ \\
\hline Similar in size to extant giraffes. & Murchison, 1868 , p.206 & $\begin{array}{l}\text { Left radius. Asiatic Museum of } \\
\text { Bengal no } 690 . \text { Nearly equal in } \\
\text { dimensions to existing giraffes. }\end{array}$ \\
\hline Similar in size to extant giraffes. & Murchison, 1868, p.207 & $\begin{array}{l}\text { Left metacarpus. Asiatic } \\
\text { Museum of Bengal no } 52 . \text { Of } \\
\text { the size of existing giraffe. }\end{array}$ \\
\hline Similar in size to extant giraffes. & Lydekker, 1885a & $\begin{array}{l}\text { Phalangeals, no 17131a. Almost } \\
\text { indistinguishable from the } \\
\text { corresponding bones of extant } \\
\text { giraffes. }\end{array}$ \\
\hline $\begin{array}{l}\text { Similar in size to extant female } \\
\text { giraffes. }\end{array}$ & Falconer \& Cautley, 1843 & $\begin{array}{l}\text { Fragments from upper and } \\
\text { lower jaws. Falconer originally }\end{array}$ \\
\hline
\end{tabular}




\begin{tabular}{|l|l|l|}
\hline & & $\begin{array}{l}\text { ascribed these specimens to } G . \\
\text { affinis. Lydeker (1876) } \\
\text { however refuted this species } \\
\text { and proposed that it in actual } \\
\text { fact G. sivalensis. }\end{array}$ \\
\hline $\begin{array}{l}\text { Larger than extant giraffes with } \\
\text { smaller teeth than extant } \\
\text { giraffes. }\end{array}$ & Mitchell \& Skinner, 2003 & Review of literature. \\
\hline
\end{tabular}


Table 2 (on next page)

Dimensions for the G. sivalensis holotype; a well preserved third cervical vertebra (OR39747)

Falconer and Cautley's (1843) findings are also presented. All values in $\mathrm{mm}$. Nomenclature is based on the Nomina Anatomica Veterinaria (International Committee on \& Veterinary Gross Anatomical Nomenclature, 2012) 


\begin{tabular}{|c|c|c|c|}
\hline Dimension and description & $\begin{array}{l}\text { Falconer \& } \\
\text { Cautley (1843)'s } \\
\text { terminology }\end{array}$ & $\begin{array}{l}\text { Present study's } \\
\text { measurement ( } \pm \\
\text { 95\% confidence } \\
\text { interval for three } \\
\text { measurements) } \\
(\mathrm{mm})\end{array}$ & $\begin{array}{l}\text { Falconer \& } \\
\text { Cautley }(1843) \\
\text { measurement } \\
(\mathrm{mm})\end{array}$ \\
\hline $\begin{array}{l}\text { Vertebral body length: } \\
\text { Longitudinal axis of the vertebral } \\
\text { body (Corpus vertebrae), from the } \\
\text { most cranial curvature of the cranial } \\
\text { extremity (Extremitas cranialis } \\
\text { [Caput vertebrae]) to the most } \\
\text { caudal part of the caudal extremity } \\
\text { (Extremitas caudalis [Fossa } \\
\text { vertebrae]) }\end{array}$ & $\begin{array}{l}\text { Length of the body } \\
\text { of the vertebrae } \\
\text { between } \\
\text { articulating heads. }\end{array}$ & $200.2 \pm 0.7$ & 198.1 \\
\hline \multirow{2}{*}{$\begin{array}{l}\text { Cranial vertebral body height: } \\
\text { Greatest dorsoventral height of } \\
\text { cranial extremity. }\end{array}$} & $\begin{array}{l}\text { Vertical height } \\
\text { articulating head? }\end{array}$ & \multirow[b]{2}{*}{$42.9 \pm 1.4$} & 25.4 \\
\hline & $\begin{array}{l}\text { Antero-posterior } \\
\text { diameter } \\
\text { articulating head? }\end{array}$ & & 48.3 \\
\hline $\begin{array}{l}\text { Cranial vertebral body width: } \\
\text { Greatest transverse width of cranial } \\
\text { extremity. }\end{array}$ & $\begin{array}{l}\text { Greatest diameter } \\
\text { at articulating head }\end{array}$ & $36.2 \pm 2.8$ & 35.6 \\
\hline $\begin{array}{l}\text { Caudal Vertebral body height: } \\
\text { Greatest dorsoventral height of } \\
\text { caudal extremity. }\end{array}$ & $\begin{array}{l}\text { Vertical diameter, } \\
\text { articular cup, } \\
\text { posterior end }\end{array}$ & $53.1 \pm 0.3$ & 50.8 \\
\hline $\begin{array}{l}\text { Caudal vertebral body width: } \\
\text { Greatest transverse width of caudal } \\
\text { extremity. }\end{array}$ & $\begin{array}{l}\text { Transverse } \\
\text { diameter, articular } \\
\text { cup, posterior end }\end{array}$ & $53.4 \pm 0.3$ & 50.8 \\
\hline $\begin{array}{l}\text { Spinous process length: From roof } \\
\text { of the vertebral foramen to the } \\
\text { highest point of the spinous process, } \\
\text { perpendicular to the long axis of the } \\
\text { vertebral body. }\end{array}$ & & $21.8 \pm 2.6$ & \\
\hline
\end{tabular}




\section{Table 3 (on next page)}

Dimensions for long bone specimens marked as belonging to $G$. sivalensis.

All values in mm. OR39749 is marked as a juvenile. Abbreviations: H: Humerus; R: Radius; Mc: Metacarpus; L: Length; Circ: Midshaft circumference; Cr: midshaft craniocaudal diameter; Tr: midshaft transverse diameter.* distal proportion lacking. † only diaphysis. ‡ proximal metaphysis missing. 


\begin{tabular}{|l|l|l|l|l|l|l|l|l|l|l|l|l|}
\hline $\begin{array}{l}\text { Specimen } \\
\text { no }\end{array}$ & HL & HCirc & HCr & HTr & RL & RCirc & RCr & RTr & McL & MCirc & McCr & McTr \\
\hline OR39750* & & & & & & & & & 389 & 186 & 53 & 60 \\
\hline OR17130 & & & & & 220 & 217 & 53 & 71 & & & & \\
\hline OR39749 & 453 & 212 & 66 & 66 & & & & & & & & \\
\hline OR17136* & 279 & 216 & 76 & 57 & & & & & & & & \\
\hline
\end{tabular}

2 
Table 4(on next page)

Summary of fossil teeth assigned to $G$. affinis by Falconer and Cautley (1843), and subsequently assigned to $G$. sivalensis. All regressions equations were obtained from Damuth (1990).

Abbreviations: TUML: Third Upper Molar Length, TUMW: Third Upper Molar Width, SUMW:

Second Upper Molar Width, TLML: Third Lower Molar Length, TLMW: Third Lower Molar Width, TLPL: Third Lower Premolar Length, TLPW: Third Lower Premolar Width, SUPL: Second Upper Premolar Length, SUPW: Second Upper Premolar Width, SD: Sample Standard Deviation 


\begin{tabular}{|c|c|c|c|c|c|}
\hline Fossil specimens & $\begin{array}{c}\text { Museum } \\
\text { no }\end{array}$ & $\begin{array}{c}\text { References to } \\
\text { specimen }\end{array}$ & Dimensions & $\begin{array}{c}\text { Relevant } \\
\text { regression } \\
\text { equation } \\
\text { (reference) }\end{array}$ & $\begin{array}{l}\text { Body mass } \\
\text { prediction }\end{array}$ \\
\hline \multirow{8}{*}{$\begin{array}{l}\text { Fragment of left maxilla } \\
\text { including two rear } \\
\text { molars. The 'back part } \\
\text { of the maxillary, beyond } \\
\text { the teeth, is attached'. }\end{array}$} & \multirow{8}{*}{$\begin{array}{l}39756 \text { a } \\
\text { (Lydekker, } \\
1885 a)\end{array}$} & \multirow{8}{*}{$\begin{array}{c}\text { Figured in Plate } 2 \\
\text { fig. 3a and 3b of } \\
\text { Falconer \& Cautley, } \\
\text { (1843). }\end{array}$} & $\begin{array}{l}\text { Joint length of two back } \\
\text { molars, maxilla } \\
=2.5 \mathrm{in}=63.5 \mathrm{~mm}\end{array}$ & & \\
\hline & & & $\begin{array}{l}\text { Greatest with of last molar } \\
\quad=1.4 \mathrm{in}=35.56 \mathrm{~mm}\end{array}$ & $\begin{array}{l}\text { 38.02xTUMW } 2.77 \\
\text { (all ungulates) }\end{array}$ & 752 kg \\
\hline & & & & $\begin{array}{l}32.36 \times \text { TUMW } \\
\text { (all selenodonts) }\end{array}$ & $945 \mathrm{~kg}$ \\
\hline & & & & $\begin{array}{l}\text { 17.78 x TUMW } \\
\text { (selenodont } \\
\text { browsers) }\end{array}$ & 718 kg \\
\hline & & & $\begin{array}{c}\text { Greatest with of } \\
\text { penultimate molar } \\
=1.45 \mathrm{in}=36.83 \mathrm{~mm}\end{array}$ & $\begin{array}{l}\text { 32.36xSUMW }{ }^{\wedge 2.78} \\
\text { (all ungulates) }\end{array}$ & $731 \mathrm{~kg}$ \\
\hline & & & & $\begin{array}{l}22.91 \times \text { SUMW}^{\wedge 2.96} \\
\text { (all selenodonts) }\end{array}$ & $991 \mathrm{~kg}$ \\
\hline & & & & $\begin{array}{c}12.02 \times \text { SUMW }^{\wedge} 3.08 \\
\text { (selondont } \\
\text { browsers) }\end{array}$ & $801 \mathrm{~kg}$ \\
\hline & & & $\begin{array}{l}\text { Average of width } \\
\text { measurements (SD) }\end{array}$ & & $823(117) \mathrm{kg}$ \\
\hline \multirow{5}{*}{$\begin{array}{c}\text { Rear molar of right } \\
\text { maxilla }\end{array}$} & \multirow{5}{*}{$\begin{array}{l}39756 \\
\text { (Lydekker, } \\
1885 a)\end{array}$} & \multirow{5}{*}{$\begin{array}{c}\text { Figured in Plate } 2 \\
\text { fig. } 4 \text { of Falconer } \\
\text { and Cautley (1843). }\end{array}$} & $\begin{array}{l}\text { Length }=1.2 \mathrm{in}=30.48 \mathrm{~mm} \\
* \text { it is not sure whether } \\
\text { this is the greatest } \\
\text { dimensions or occlusal } \\
\text { surface. }\end{array}$ & $\begin{array}{c}19.50 \times \mathrm{TUMLL}^{\wedge 2.81} \\
\text { (all ungulates) }\end{array}$ & $288 \mathrm{~kg}$ \\
\hline & & & & $\begin{array}{l}8.71 \text { x TUML }{ }^{\wedge 3.12} \\
\text { (all selenodonts) }\end{array}$ & $372 \mathrm{~kg}$ \\
\hline & & & & $\begin{array}{l}6.31 \times \text { TUML }^{\wedge .29} \\
\text { (selenodont } \\
\text { browsers) }\end{array}$ & $481 \mathrm{~kg}$ \\
\hline & & & $\begin{array}{l}\text { Average of length } \\
\text { measurements (SD) }\end{array}$ & & $380(97) \mathrm{kg}$ \\
\hline & & & $\begin{array}{l}\text { Width }=1.4 \text { in }=35.56 \mathrm{~mm} \\
*^{*} \text { it is not sure whether } \\
\text { this is the greatest } \\
\text { dimensions or occlusal }\end{array}$ & $\begin{array}{l}\text { 38.02xTUMW } \\
\text { (all ungulates) }\end{array}$ & $752 \mathrm{~kg}$ \\
\hline
\end{tabular}




\begin{tabular}{|c|c|c|c|c|c|}
\hline Fossil specimens & $\begin{array}{c}\text { Museum } \\
\text { no }\end{array}$ & $\begin{array}{c}\text { References to } \\
\text { specimen }\end{array}$ & Dimensions & $\begin{array}{c}\text { Relevant } \\
\text { regression } \\
\text { equation } \\
\text { (reference) }\end{array}$ & $\begin{array}{l}\text { Body mass } \\
\text { prediction }\end{array}$ \\
\hline & & & surface. & & \\
\hline & & & & $\begin{array}{l}32.36 \times \text { TUMW^2.87 } \\
\text { (all selenodonts) }\end{array}$ & $915 \mathrm{~kg}$ \\
\hline & & & & $\begin{array}{l}17.78 \times \text { TUMW}^{\wedge} .97 \\
\text { (selenodont } \\
\text { browsers) }\end{array}$ & $718 \mathrm{~kg}$ \\
\hline & & & $\begin{array}{l}\text { Average of width } \\
\text { measurements (SD) }\end{array}$ & & 795 (105) kg \\
\hline \multirow{8}{*}{$\begin{array}{l}\text { Fragment of left } \\
\text { mandible containing the } \\
\text { third molar }\end{array}$} & \multirow{8}{*}{$\begin{array}{l}39755 \\
\text { (Lydekker, } \\
\text { 1885a) }\end{array}$} & \multirow{8}{*}{$\begin{array}{c}\text { Figured in plate } 2 \\
\text { figure } 5 a \text { and } 5 b \text { of } \\
\text { Falconer } \& \text { Cautley, } \\
\text { (1843). }\end{array}$} & Length $=1.7 \mathrm{in}=43.18 \mathrm{~mm}$ & $\begin{array}{l}6.31 \times \mathrm{TLML}^{\wedge 2.99} \\
\text { (all ungulates) }\end{array}$ & $489 \mathrm{~kg}$ \\
\hline & & & & $\begin{array}{l}3.24 \times \text { TLMLL }^{\wedge .19} \\
\text { (all selenodonts) }\end{array}$ & $533 \mathrm{~kg}$ \\
\hline & & & & $\begin{array}{c}2.24 \times \mathrm{TLML}^{\wedge 3.35} \\
\text { (selenodont } \\
\text { browsers) }\end{array}$ & $673 \mathrm{~kg}$ \\
\hline & & & $\begin{array}{c}\text { Average of length } \\
\text { measurements (SD) }\end{array}$ & & $565(96) \mathrm{kg}$ \\
\hline & & & $\begin{aligned} & \text { Greatest width } \\
= & 1.0 \mathrm{in}=25.4 \mathrm{~mm}\end{aligned}$ & $\begin{array}{c}\text { 109.64xTLMW }{ }^{\wedge 2.73} \\
\text { (all ungulates) }\end{array}$ & $750 \mathrm{~kg}$ \\
\hline & & & & $\begin{array}{l}77.62 \times \text { TLMW }^{\wedge 2.93} \\
\text { (all selenodonts) }\end{array}$ & $1014 \mathrm{~kg}$ \\
\hline & & & & $\begin{array}{c}\text { 64.56x TLMW }{ }^{\wedge 2.88} \\
\text { (selenodont } \\
\text { browsers) }\end{array}$ & $718 \mathrm{~kg}$ \\
\hline & & & $\begin{array}{c}\text { Average of width } \\
\text { measurements (SD) }\end{array}$ & & $827(162) \mathrm{kg}$ \\
\hline \multirow{8}{*}{$\begin{array}{l}\text { Third premolar of the } \\
\text { left mandible, detached. }\end{array}$} & \multirow{8}{*}{$\begin{array}{c}39757 \\
\text { (Lydekker, } \\
\text { 1885a) }\end{array}$} & \multirow{8}{*}{$\begin{array}{l}\text { Figured in Plate } 2 \\
\text { figure } 6 \text { of Falconer } \\
\text { \& Cautley, (1843). }\end{array}$} & Length $=1.0 \mathrm{in}=25.4 \mathrm{~mm}$ & $\begin{array}{l}79.43 \times T L P L^{\wedge 2.76} \\
\text { (all ungulates) }\end{array}$ & $599 \mathrm{~kg}$ \\
\hline & & & & $\begin{array}{l}\text { 61.66xTLPL }{ }^{\wedge 2.92} \\
\text { (all selenodonts) }\end{array}$ & $780 \mathrm{~kg}$ \\
\hline & & & & $\begin{array}{c}20.42 \times \mathrm{TLPL}^{\wedge 3.19} \\
\text { (selenodont } \\
\text { browsers) }\end{array}$ & $618 \mathrm{~kg}$ \\
\hline & & & $\begin{array}{c}\text { Average of length } \\
\text { measurements (SD) }\end{array}$ & & 666 (99) kg \\
\hline & & & Width $=0.9 \mathrm{in}=22.86 \mathrm{~mm}$ & $\begin{array}{c}\text { 524.81xTLPW }{ }^{\wedge 2.45} \\
\text { (all ungulates) }\end{array}$ & $1121 \mathrm{~kg}$ \\
\hline & & & & $\begin{array}{l}\text { 524.81x TLPW }{ }^{\wedge 2.53} \\
\text { (all selenodonts) }\end{array}$ & $1440 \mathrm{~kg}$ \\
\hline & & & & $\begin{array}{c}398.11 \times \text { TLPW }^{\wedge 2.49} \\
\text { (selenodont } \\
\text { browsers) }\end{array}$ & $964 \mathrm{~kg}$ \\
\hline & & & $\begin{array}{c}\text { Average of width } \\
\text { measurements (SD) }\end{array}$ & & $1175(243) \mathrm{kg}$ \\
\hline $\begin{array}{l}\text { Second premolar of } \\
\text { right maxilla }\end{array}$ & & $\begin{array}{l}\text { Figured in Plate } 2 \\
\text { figure } 7 \text { of Falconer } \\
\text { \& Cautley, (1843). }\end{array}$ & Length $=1.0 \mathrm{in}=25.4 \mathrm{~mm}$ & $\begin{array}{c}\text { 169.82xSUPL } \\
\text { (all ungulates) }\end{array}$ & $570 \mathrm{~kg}$ \\
\hline
\end{tabular}




\begin{tabular}{|c|c|c|c|c|c|}
\hline Fossil specimens & $\begin{array}{c}\text { Museum } \\
\text { no }\end{array}$ & $\begin{array}{c}\text { References to } \\
\text { specimen }\end{array}$ & Dimensions & $\begin{array}{l}\text { Relevant } \\
\text { regression } \\
\text { equation } \\
\text { (reference) }\end{array}$ & $\begin{array}{l}\text { Body mass } \\
\text { prediction }\end{array}$ \\
\hline & & & & $\begin{array}{l}141.25 \times \text { SUPL }^{\wedge 2.65} \\
\text { (all selenodonts) }\end{array}$ & $746 \mathrm{~kg}$ \\
\hline & & & & $\begin{array}{c}\text { 20.41xSUPL } \\
\text { (selenodont } \\
\text { browsers) }\end{array}$ & $776 \mathrm{~kg}$ \\
\hline & & & $\begin{array}{c}\text { Average of length } \\
\text { measurements (SD) }\end{array}$ & & $697(111) \mathrm{kg}$ \\
\hline & & & $\begin{array}{l}\text { Width } \\
=1.12 \mathrm{in}=28.45 \mathrm{~mm}\end{array}$ & $\begin{array}{c}\text { 380.19xSUPW } \\
\text { (all ungulates) }\end{array}$ & $840 \mathrm{~kg}$ \\
\hline & & & & $\begin{array}{l}\text { 416.87xSUPW } 2.31 \\
\text { (all selenodonts) }\end{array}$ & $953 \mathrm{~kg}$ \\
\hline & & & & $\begin{array}{l}\text { 208.93x SUPW }{ }^{\wedge 2.44} \\
\text { (selenodont } \\
\text { browsers) }\end{array}$ & $738 \mathrm{~kg}$ \\
\hline & & & $\begin{array}{l}\text { Average of width } \\
\text { measurements (SD) }\end{array}$ & & $843(108) \mathrm{kg}$ \\
\hline
\end{tabular}

2 


\section{Table 5(on next page)}

The studied okapi specimens and their dimensions used in determining the appropriateness of allometric equations in determining body size and shape estimates in G. sivalensis.

Abbreviations: DMNH: Ditsong National Museum of Natural History (Formerly Transvaal Museum), Pretoria, South Africa; MNHN: Museum National d'Histoire Naturelle, Paris, France; SM: Senckenberg Naturmuseum, Frankfurt, Germany; OTVL: Observed Total Vertebral Length; ONL: Observed Neck Length; ONL-1: Observed Neck Length Minus C1; OTL: Observed Trunk Length; OFL: Observed Front Limb Long Bone Lengths; OHL: Observed Hind Limb Long Bone Lengths; N:FL: Neck Length to Foreleg Length ratio; PNL: Predicted Neck Length; \% PE: Percent Prediction Error for vertebral length based on giraffe ontogenetic allometry. 
PeerJ Reviewing Manuscript

1

\begin{tabular}{|c|c|c|c|c|c|c|c|c|c|c|}
\hline Specimen no & Museum & OTVL & OVNL & OVNL-1 & C3VBL & OFL & $\mathrm{N}: \mathrm{FL}$ & PVNL & $\begin{array}{l}\text { Predicted neck length regression } \\
\text { equation }\end{array}$ & \%PE \\
\hline az2348 & DMNH & 1259 & 557 & 522 & 85 & 932 & 0.60 & 586 & \multirow{10}{*}{$\mathrm{PVNL}=10.65 * \mathrm{C}^{*} \mathrm{VBL}^{\wedge .0902}$} & 0.05 \\
\hline az2440 & DMNH & 1392 & 567 & 531 & 83 & & & 574 & & 0.01 \\
\hline $1973-178$ & MNHN & 722 & 273 & 260 & 42 & 752 & 0.36 & 310 & & 0.14 \\
\hline 1961-131 & MNHN & 400 & 149 & 137 & 22.1 & 553 & 0.27 & 174 & & 0.17 \\
\hline $1984-56$ & MNHN & & 459 & 428 & 73.5 & & & 514 & & 0.12 \\
\hline 1996-102 & MNHN & 1529 & 632 & 600 & 96.9 & 1018 & 0.62 & 660 & & 0.04 \\
\hline 27194 & SM & 1442 & 621 & 589 & 106 & 1018 & 0.61 & 715 & & 0.15 \\
\hline 73224 & SM & 1521 & 647 & 613 & 107 & 993 & 0.65 & 722 & & 0.12 \\
\hline 56346 & SM & 1458 & 630 & 599 & 102 & 998 & 0.63 & 691 & & 0.10 \\
\hline 92290 & SM & & & 142 & 22 & 534 & & & & \\
\hline
\end{tabular}

2 
Table 6(on next page)

Power functions, their origin and predicted values for linear dimensions of $G$. sivalensis. 


\begin{tabular}{|c|c|c|c|c|}
\hline $\begin{array}{l}\text { Dimension } \\
\text { predicted for } \\
\text { G. sivalensis } \\
\text { (dependent }(y) \\
\text { variable) }\end{array}$ & $\begin{array}{l}\text { Prediction based } \\
\text { on (independent } \\
\text { (x) variable) }\end{array}$ & $\begin{array}{l}\text { Equation } \\
\text { generated } \\
\text { from }\end{array}$ & $\begin{array}{l}\text { Equation, } \\
\text { Slope Confidence } \\
\text { interval, } \\
\mathbf{R}^{2}\end{array}$ & Prediction \\
\hline $\begin{array}{l}\text { Vertebral neck length } \\
\text { (C1 to } \mathrm{C} 7\end{array}$ & $\begin{array}{l}\text { OR39747 (C3) vertebral } \\
\text { body length }\end{array}$ & $\begin{array}{l}\text { G. camelopardalis } \\
\text { ontogenetic data }\end{array}$ & $\begin{array}{c}\mathrm{y}=10.66 \mathrm{x}^{0.902} \\
\mathrm{Cl}=0.874-0.930 \\
\mathrm{R}^{2}=0.99\end{array}$ & $1270 \mathrm{~mm}$ \\
\hline $\begin{array}{l}\text { Vertebral neck length } \\
\text { (C2 to } \mathrm{C} 7 \text { ) }\end{array}$ & $\begin{array}{l}\text { OR39747 (C3) vertebral } \\
\text { body length }\end{array}$ & $\begin{array}{l}\text { G. camelopardalis } \\
\text { ontogenetic data }\end{array}$ & $\begin{array}{c}y=9.708 x^{\wedge 0.908} \\
C l=0.881-0.936 \\
R^{2}=0.99\end{array}$ & $1195 \mathrm{~mm}$ \\
\hline $\begin{array}{l}\text { Vertebral neck length } \\
\text { (C2 to } \mathrm{C} 7 \text { ) }\end{array}$ & $\begin{array}{l}\text { OR39747 (C3) vertebral } \\
\text { body length }\end{array}$ & $\begin{array}{l}\text { Various ungulates, } \\
\text { data from } \\
\text { (Badlangana, } \\
\text { Adams \& Manger, } \\
\text { 2009) }\end{array}$ & $\begin{array}{c}y=5.023 x^{1.025} \\
C l=0.977-1.614 \\
R^{2}=0.99\end{array}$ & $1148 \mathrm{~mm}$ \\
\hline $\begin{array}{l}\text { Dorsal neck length } \\
\text { (occipital crest to } \\
\text { withers) }\end{array}$ & $\begin{array}{l}\text { OR39747 (C3) vertebral } \\
\text { body length }\end{array}$ & $\begin{array}{l}\text { G. camelopardalis } \\
\text { ontogenetic data }\end{array}$ & $\begin{array}{c}\mathrm{y}=1.694 \mathrm{x}^{0.822} \\
\mathrm{Cl}=0.716-0.928 \\
\mathrm{R}^{2}=0.87\end{array}$ & $1321 \mathrm{~mm}$ \\
\hline $\begin{array}{l}\text { Ventral neck length } \\
\text { (angle of jaw to } \\
\text { acromion) }\end{array}$ & $\begin{array}{l}\text { OR39747 (C3) vertebral } \\
\text { body length }\end{array}$ & $\begin{array}{l}\text { G. camelopardalis } \\
\text { ontogenetic data }\end{array}$ & $\begin{array}{c}\mathrm{y}=1.442 \mathrm{x}^{0.890} \\
\mathrm{Cl}=0.765-1.014 \\
\mathrm{R}^{2}=0.85\end{array}$ & $1608 \mathrm{~mm}$ \\
\hline $\begin{array}{l}\text { Average neck length } \\
\text { (of dorsal and ventral } \\
\text { neck length) }\end{array}$ & $\begin{array}{l}\text { OR39747 (C3) vertebral } \\
\text { body length }\end{array}$ & $\begin{array}{l}\text { G. camelopardalis } \\
\text { ontogenetic data }\end{array}$ & $\begin{array}{c}\mathrm{y}=1.55 \mathrm{x}^{0.859} \\
\mathrm{Cl}=0.767-0.951 \\
\mathrm{R}^{2}=0.91\end{array}$ & $1467 \mathrm{~mm}$ \\
\hline $\begin{array}{l}\text { Front leg length } \\
\text { (humerus+ radius+ } \\
\text { metacarpus long } \\
\text { bones) }\end{array}$ & $\begin{array}{l}\text { OR39747 (C3) vertebral } \\
\text { body length }\end{array}$ & $\begin{array}{l}\text { G. camelopardalis } \\
\text { ontogenetic data }\end{array}$ & $\begin{array}{c}\mathrm{y}=70.2 \mathrm{x}^{0.598} \\
\mathrm{Cl}=0.332-0.8642 \\
\mathrm{R}^{2}=0.87\end{array}$ & $1668 \mathrm{~mm}$ \\
\hline Foreleg withers height & $\begin{array}{l}\text { OR39747 (C3) vertebral } \\
\text { body length }\end{array}$ & $\begin{array}{l}\text { G. camelopardalis } \\
\text { ontogenetic data }\end{array}$ & $\begin{array}{c}\mathrm{y}=7.61 \mathrm{x}^{0.663} \\
\mathrm{Cl}=0.586-0.741 \\
\mathrm{R}^{2}=0.92\end{array}$ & $2558 \mathrm{~mm}$ \\
\hline $\begin{array}{l}\text { Approximate reaching } \\
\text { height (hoof to } \\
\text { occipital crest) }\end{array}$ & $\begin{array}{l}\text { OR39747 (C3) vertebral } \\
\text { body length }\end{array}$ & $\begin{array}{l}\text { G. camelopardalis } \\
\text { ontogenetic data }\end{array}$ & $\begin{array}{c}\mathrm{y}=7.600 \mathrm{x}^{0.742} \\
\mathrm{Cl}=0.678-0.806 \\
\mathrm{R}^{2}=0.95\end{array}$ & $3880 \mathrm{~mm}$ \\
\hline
\end{tabular}




\section{Table 7 (on next page)}

Functions for the prediction of body mass based on various $G$. sivalensis specimens.

$\mathrm{SD}=$ Standard deviation $. \mathrm{PE}=$ Prediction Error 


\begin{tabular}{|c|c|c|c|c|c|c|}
\hline $\begin{array}{l}\text { Independent(x) } \\
\text { variable }\end{array}$ & Model sample & $\begin{array}{l}\text { Model } \\
\text { r2 }\end{array}$ & Allometric equation & $\begin{array}{l}\text { Body mass } \\
\text { prediction } \\
\quad(\mathrm{kg})\end{array}$ & $\begin{array}{l}\text { Body mass PE\% } \\
\text { confidence } \\
\text { intervals in kg } \\
\text { (based on } \\
\text { prediction } \\
\text { errors when } \\
\text { applied to G. } \\
\text { camelopardalis } \\
\text { data) } \\
\end{array}$ & $\begin{array}{c}\text { Body mass } \\
\text { confidence } \\
\text { intervals in } \\
\text { kg (based on } \\
\text { prediction } \\
\text { errors when } \\
\text { applied to } O \text {. } \\
\text { johnstoni } \\
\text { data }\end{array}$ \\
\hline $\begin{array}{l}\text { OR39747 (C3) } \\
\text { vertebral body } \\
\text { length }\end{array}$ & $\begin{array}{l}\text { G. camelopardalis } \\
\text { ontogenetic data }\end{array}$ & 0.91 & $y=0.022 * x^{\wedge 1.919}$ & 575 & $\begin{array}{c}8 \% \mathrm{PE} \\
(529-612)\end{array}$ & $\begin{array}{c}81 \% \text { PE } \\
(109-1041)\end{array}$ \\
\hline OR39747 (C3) cr dv & $\begin{array}{l}\text { G. camelopardalis } \\
\text { ontogenetic data }\end{array}$ & 0.77 & $y=0.0023 * x^{\wedge 3.21}$ & 400 & $\begin{array}{c}18 \% \mathrm{PE} \\
(328-472)\end{array}$ & $\begin{array}{l}87 \% \text { PE } \\
(52-748)\end{array}$ \\
\hline OR39747 (C3) cr lat & $\begin{array}{l}\text { G. camelopardalis } \\
\text { ontogenetic data }\end{array}$ & 0.84 & $y=0.0054 * x^{\wedge 2.967}$ & 228 & $\begin{array}{c}14 \% \mathrm{PE} \\
(196-260)\end{array}$ & $\begin{array}{l}99 \% \text { PE } \\
(2-454) \\
\end{array}$ \\
\hline OR39747 (C3) cd dv & $\begin{array}{l}\text { G. camelopardalis } \\
\text { ontogenetic data }\end{array}$ & 0.69 & $y=0.0048 * x^{\wedge 2.847}$ & 390 & $\begin{array}{c}25 \% \mathrm{PE} \\
(293-487) \\
\end{array}$ & $\begin{array}{c}17 \% \mathrm{PE} \\
(323-456)\end{array}$ \\
\hline OR39747 (C3) cd lat & $\begin{array}{l}\text { G. camelopardalis } \\
\text { ontogenetic data }\end{array}$ & 0.57 & $y=0.0227^{*} x^{\wedge 2.360}$ & 271 & $\begin{array}{c}50 \% \text { PE } \\
(136-407)\end{array}$ & $\begin{array}{c}21 \% \mathrm{PE} \\
(214-328)\end{array}$ \\
\hline $\begin{array}{c}\text { Average of OR39747 } \\
\text { vertebral } \\
\text { dimensions } \\
\text { (SD) }\end{array}$ & & & & $\begin{array}{c}373 \\
(135)\end{array}$ & & \\
\hline OR39748 (C3) cd dv & $\begin{array}{l}\text { G. camelopardalis } \\
\text { ontogenetic data }\end{array}$ & 0.69 & $y=0.0048^{*} x^{\wedge 2.847}$ & 394 & $\begin{array}{c}25 \% \text { PE } \\
(296-493)\end{array}$ & $\begin{array}{c}17 \% \mathrm{PE} \\
(327-462)\end{array}$ \\
\hline OR39747 (C4) cd dv & $\begin{array}{l}\text { G. camelopardalis } \\
\text { ontogenetic data }\end{array}$ & 0.69 & $y=0.0011^{*} x^{\wedge 3.128}$ & 274 & & \\
\hline OR39747 (C5) cd dv & $\begin{array}{l}\text { G. camelopardalis } \\
\text { ontogenetic data }\end{array}$ & 0.69 & $Y=0.0004 * x^{\wedge 3.285}$ & 187 & & \\
\hline $\begin{array}{c}\text { Humerus midshaft } \\
\text { circumference } \\
\text { (OR17136) }\end{array}$ & $\begin{array}{l}\text { G. camelopardalis } \\
\text { ontogenetic data }\end{array}$ & 0.98 & $y=8.96 * 10^{-4} x^{\wedge 2.55}$ & 809 & $\begin{array}{c}5 \% \mathrm{PE} \\
(767-851)\end{array}$ & $\begin{array}{c}5 \% \mathrm{PE} \\
(766-852)\end{array}$ \\
\hline $\begin{array}{c}\text { Humerus midshaft } \\
\text { circumference } \\
\text { (OR39749) }\end{array}$ & $\begin{array}{l}\text { G. camelopardalis } \\
\text { ontogenetic data }\end{array}$ & & & 772 & $\begin{array}{c}5 \% \mathrm{PE} \\
(732-812)\end{array}$ & $\begin{array}{c}5 \% \mathrm{PE} \\
(731-813)\end{array}$ \\
\hline $\begin{array}{l}\text { average of humeral } \\
\text { circumferences } \\
\text { (SD) }\end{array}$ & & & & $\begin{array}{l}791 \\
(26)\end{array}$ & & \\
\hline $\begin{array}{c}\text { Humerus midshaft } \\
\text { craniocaudal } \\
\text { diameter (OR17136) }\end{array}$ & $\begin{array}{l}\text { G. camelopardalis } \\
\text { ontogenetic data }\end{array}$ & 0.98 & $y=3.59 * 10^{-2} x^{\wedge 2.32}$ & 834 & $\begin{array}{c}11 \% \text { PE } \\
(743-925)\end{array}$ & $\begin{array}{c}13 \% \mathrm{PE} \\
(723-945)\end{array}$ \\
\hline $\begin{array}{c}\text { Humerus midshaft } \\
\text { craniocaudal } \\
\text { diameter (OR39749) }\end{array}$ & $\begin{array}{l}\text { G. camelopardalis } \\
\text { ontogenetic data }\end{array}$ & & $y=3.59 * 10-2 x^{\wedge 2.32}$ & 602 & $\begin{array}{c}11 \% \text { PE } \\
(537-667)\end{array}$ & $\begin{array}{c}13 \% \mathrm{PE} \\
(522-682)\end{array}$ \\
\hline $\begin{array}{c}\text { Humerus midshaft } \\
\text { transverse diameter } \\
\text { (OR17136) }\end{array}$ & $\begin{array}{l}\text { G. camelopardalis } \\
\text { ontogenetic data }\end{array}$ & 0.96 & $y=2.00 * 10-2 x^{\wedge 2.53}$ & 561 & $\begin{array}{c}24 \% \mathrm{PE} \\
(429-693)\end{array}$ & $\begin{array}{c}22 \% \mathrm{PE} \\
(438-684)\end{array}$ \\
\hline $\begin{array}{c}\text { Humerus midshaft } \\
\text { transverse diameter } \\
\text { (OR39749) }\end{array}$ & $\begin{array}{l}\text { G. camelopardalis } \\
\text { ontogenetic data }\end{array}$ & & $y=2.00 * 10-2 x^{\wedge 2.53}$ & 813 & $\begin{array}{c}24 \% \mathrm{PE} \\
(622-1004)\end{array}$ & $\begin{array}{c}22 \% \mathrm{PE} \\
(635-991)\end{array}$ \\
\hline $\begin{array}{l}\text { Average humeral } \\
\text { craniocaudal and } \\
\text { transverse (SD) }\end{array}$ & & & & $\begin{array}{c}703 \\
(141)\end{array}$ & & \\
\hline $\begin{array}{c}\text { All humeral } \\
\text { ontogenetic average }\end{array}$ & & & & $\begin{array}{c}732 \\
(119)\end{array}$ & & \\
\hline
\end{tabular}




\begin{tabular}{|c|c|c|c|c|c|c|}
\hline (SD) & & & & & & \\
\hline $\begin{array}{c}\text { Radius midshaft } \\
\text { circumference } \\
\text { (OR17130) }\end{array}$ & $\begin{array}{l}\text { G. camelopardalis } \\
\text { ontogenetic data }\end{array}$ & 0.99 & $y=1.65 * 10-4 x^{\wedge 2.93}$ & 1179 & $\begin{array}{c}10 \% \mathrm{PE} \\
(1064-1294)\end{array}$ & $\begin{array}{c}31 \% \mathrm{PE} \\
(726-1390)\end{array}$ \\
\hline $\begin{array}{c}\text { Radius midshaft } \\
\text { craniocaudal } \\
\text { diameter (OR17130) }\end{array}$ & $\begin{array}{l}\text { G. camelopardalis } \\
\text { ontogenetic data }\end{array}$ & 0.98 & $y=2.89 * 10-3 x^{\wedge 3.19}$ & 847 & $\begin{array}{c}12 \% \mathrm{PE} \\
(746-948)\end{array}$ & $\begin{array}{c}62 \% \mathrm{PE} \\
(416-1780)\end{array}$ \\
\hline $\begin{array}{c}\text { Radius midshaft } \\
\text { transverse diameter } \\
\text { (OR17130) } \\
\end{array}$ & $\begin{array}{l}\text { G. camelopardalis } \\
\text { ontogenetic data }\end{array}$ & 0.99 & $y=1.18 * 10-2 x^{\wedge 2.67}$ & 1047 & $\begin{array}{c}9 \% \mathrm{PE} \\
(948-1146)\end{array}$ & $\begin{array}{c}19 \% \mathrm{PE} \\
(943-1387)\end{array}$ \\
\hline $\begin{array}{c}\text { Radius ontogenetic } \\
\text { average } \\
\text { (SD) }\end{array}$ & & & & $\begin{array}{l}1024 \\
(167)\end{array}$ & & \\
\hline $\begin{array}{l}\text { Metacarpal } \\
\text { midshaft } \\
\text { circumference } \\
\text { (OR39750) }\end{array}$ & $\begin{array}{l}\text { G. camelopardalis } \\
\text { ontogenetic data }\end{array}$ & 0.96 & $y=4.70 * 10-5 x^{\wedge 3.24}$ & 1058 & $\begin{array}{c}11 \% \mathrm{PE} \\
(942-1174)\end{array}$ & $\begin{array}{c}\text { 31\%PE } \\
(726-1390)\end{array}$ \\
\hline $\begin{array}{c}\text { Metacarpal } \\
\text { midshaft } \\
\text { craniocaudal } \\
\text { diameter (OR39750) }\end{array}$ & $\begin{array}{l}\text { G. camelopardalis } \\
\text { ontogenetic data }\end{array}$ & 0.97 & $y=1.59 * 10-3 x^{\wedge 3.40}$ & 1098 & $\begin{array}{c}21 \% \text { PE } \\
(867-1329)\end{array}$ & $\begin{array}{c}62 \% \mathrm{PE} \\
(416-1780)\end{array}$ \\
\hline $\begin{array}{c}\text { Metacarpal } \\
\text { midshaft transverse } \\
\text { diameter (OR39750) }\end{array}$ & $\begin{array}{l}\text { G. camelopardalis } \\
\text { ontogenetic data }\end{array}$ & 0.98 & $y=6.71 * 10-3 x^{\wedge 2.95}$ & 1165 & $\begin{array}{c}20 \% \text { PE } \\
(932-1398)\end{array}$ & $\begin{array}{c}19 \% \mathrm{PE} \\
(943-1387)\end{array}$ \\
\hline Average metacarpus & & & & $\begin{array}{c}1107 \\
(54) \\
\end{array}$ & & \\
\hline $\begin{array}{l}\text { Humerus midshaft } \\
\text { craniocaudal } \\
\text { diameter (OR17136) }\end{array}$ & $\begin{array}{c}\text { Artiodactyl } \\
\text { interspecific } \\
\text { allometry (Scott, } \\
1990)\end{array}$ & 0.94 & $y=7.63 x^{\wedge 2.455}$ & 1106 & $\begin{array}{c}18 \% \mathrm{PE} \\
(906-1305)\end{array}$ & $\begin{array}{c}24 \% \mathrm{PE} \\
(844-1368)\end{array}$ \\
\hline $\begin{array}{l}\text { Humerus midshaft } \\
\text { craniocaudal } \\
\text { diameter (OR39749) }\end{array}$ & $\begin{array}{c}\text { Artiodactyl } \\
\text { interspecific } \\
\text { allometry (Scott, } \\
1990)\end{array}$ & & & 793 & $\begin{array}{c}18 \% \mathrm{PE} \\
(650-936)\end{array}$ & $\begin{array}{c}24 \% \mathrm{PE} \\
(605-981)\end{array}$ \\
\hline $\begin{array}{c}\text { Humerus midshaft } \\
\text { transverse diameter } \\
\text { (OR17136) }\end{array}$ & $\begin{array}{c}\text { Artiodactyl static } \\
\text { interspecific } \\
\text { (Scott, 1990) }\end{array}$ & 0.95 & $y=12.4 x^{\wedge 2.46}$ & 900 & $\begin{array}{c}26 \% \mathrm{PE} \\
(662-1138)\end{array}$ & $\begin{array}{c}52 \% \mathrm{PE} \\
(428-1372)\end{array}$ \\
\hline $\begin{array}{l}\text { Humerus midshaft } \\
\text { transverse diameter } \\
\text { (OR39749) }\end{array}$ & $\begin{array}{c}\text { Artiodactyl } \\
\text { interspecific } \\
\text { allometry (Scott, } \\
\text { 1990) }\end{array}$ & & & 1268 & $\begin{array}{c}26 \% \text { PE } \\
(822-1518)\end{array}$ & $\begin{array}{c}52 \% \\
(603-1933)\end{array}$ \\
\hline $\begin{array}{l}\text { Humerus midshaft } \\
\text { circumference } \\
\text { (OR17136) }\end{array}$ & $\begin{array}{c}\text { Various } \\
\text { mammalian taxa } \\
\text { (Roth, 1990) }\end{array}$ & 0.99 & $y=9.45^{*} 10^{\wedge-4} x^{\wedge 2.61}$ & 1170 & $\begin{array}{c}30 \% \mathrm{PE} \\
(822-1518)\end{array}$ & $\begin{array}{c}29 \% \mathrm{PE} \\
(831-1509)\end{array}$ \\
\hline $\begin{array}{c}\text { Humerus midshaft } \\
\text { circumference } \\
\text { (OR39749) }\end{array}$ & $\begin{array}{c}\text { Various } \\
\text { mammalian taxa } \\
\text { (Roth, 1990) } \\
\end{array}$ & & & 1115 & $\begin{array}{c}30 \% \mathrm{PE} \\
(784-1446)\end{array}$ & $\begin{array}{c}29 \% \mathrm{PE} \\
(792-1438)\end{array}$ \\
\hline $\begin{array}{l}\text { Humerus midshaft } \\
\text { circumference } \\
\text { (OR17136) }\end{array}$ & $\begin{array}{c}\text { Various } \\
\text { mammalian taxa } \\
\text { (Anderson, Hall- } \\
\text { Martin \& Russell, } \\
\text { 1985) } \\
\end{array}$ & 0.99 & $0.0009 x^{\wedge 2.6392}$ & 1304 & $\begin{array}{c}37 \% \mathrm{PE} \\
(819-1789)\end{array}$ & $\begin{array}{c}35 \% \mathrm{PE} \\
(842-1766)\end{array}$ \\
\hline $\begin{array}{l}\text { Humerus midshaft } \\
\text { circumference } \\
\text { (OR39749) }\end{array}$ & $\begin{array}{c}\text { Various } \\
\text { mammalian taxa } \\
\text { (Anderson, Hall- } \\
\text { Martin \& Russell, }\end{array}$ & & & 1241 & $\begin{array}{c}37 \% \text { PE } \\
(780-1702)\end{array}$ & $\begin{array}{c}35 \% \mathrm{PE} \\
(801-1681)\end{array}$ \\
\hline
\end{tabular}




\begin{tabular}{|c|c|c|c|c|c|c|}
\hline & 1985) & & & & & \\
\hline $\begin{array}{l}\text { Humerus midshaft } \\
\text { circumference } \\
\text { (OR17136) }\end{array}$ & $\begin{array}{c}\text { Ungulates } \\
\text { (Campione \& } \\
\text { Evans, 2012) }\end{array}$ & 0.95 & $y=1.469 x^{\wedge 2.5273}$ & 1167 & $\begin{array}{c}29 \% \mathrm{PE} \\
(831-1503)\end{array}$ & $\begin{array}{c}31 \% \mathrm{PE} \\
(800-1534)\end{array}$ \\
\hline $\begin{array}{l}\text { Humerus midshaft } \\
\text { circumference } \\
\text { (OR39749) }\end{array}$ & $\begin{array}{c}\text { Ungulates } \\
\text { (Campione \& } \\
\text { Evans, 2012) }\end{array}$ & & & 1113 & $\begin{array}{c}29 \% \mathrm{PE} \\
(792-1433)\end{array}$ & $\begin{array}{c}31 \% \mathrm{PE} \\
(763-1463)\end{array}$ \\
\hline $\begin{array}{l}\text { All humeral } \\
\text { interspecific } \\
\text { average } \\
\text { (SD) } \\
\end{array}$ & & & & $\begin{array}{l}1112 \\
(180)\end{array}$ & & \\
\hline $\begin{array}{c}\text { Radius midshaft } \\
\text { craniocaudal } \\
\text { diameter (OR } \\
17130) \\
\end{array}$ & $\begin{array}{c}\text { Artiodactyl static } \\
\text { allometry (Scott, } \\
\text { 1990) }\end{array}$ & 0.93 & $y=29.2 x^{\wedge 2.51}$ & 1891 & $\begin{array}{c}50 \% \mathrm{PE} \\
946-2837\end{array}$ & $\begin{array}{c}54 \% \mathrm{PE} \\
870-2911\end{array}$ \\
\hline $\begin{array}{c}\text { Radius midshaft } \\
\text { transverse diameter } \\
\text { (OR 17130) }\end{array}$ & $\begin{array}{c}\text { Artiodactyl static } \\
\text { allometry (Scott, } \\
1990)\end{array}$ & 0.91 & $y=8.19 x^{\wedge 2.555}$ & 1238 & $\begin{array}{c}11 \% \mathrm{PE} \\
1102-1374\end{array}$ & $\begin{array}{c}43 \% \mathrm{PE} \\
(711-1765)\end{array}$ \\
\hline $\begin{array}{c}\text { Radial interspecific } \\
\text { average } \\
\text { (SD) }\end{array}$ & & & & $\begin{array}{l}1565 \\
(462)\end{array}$ & & \\
\hline
\end{tabular}

2 